\title{
Synthesis of chromeno[2,3-b]carbazole and chromeno[3,2-f]indazole derivatives. A new class of indole- and pyrazole-fused polycyclic compounds using $o$-quinodimethane chemistry. A reactivity and regioselectivity computational study
}

\author{
Michalis A. Terzidis, Constantinos A. Tsoleridis, * and Julia Stephanidou-Stephanatou \\ Department of Chemistry, Laboratory of Organic Chemistry, University of Thessaloniki, 54124, \\ Macedonia, Greece \\ E-mail: tsolerid@chem.auth.gr,ioulia@chem.auth.gr
}

\begin{abstract}
An efficient route to the new classes of derivatives tetrahydrochromeno[2,3-b]carbazoles and tetrahydrochromeno[3,2-f]indazoles has been developed. The cycloaddition reactions of chromones 3 and 4 with indole-o-quinodimethane $\mathbf{2}$ gave a diastereomeric mixture of DielsAlder cycloadducts 5-8 in good yields, whereas the corresponding reactions of chromones $\mathbf{3}$ with pyrazole- $o$-quinodimethane $\mathbf{1 0}$ were more regioselective giving only cycloadducts $\mathbf{1 1}$ and 12 along with a small amount of the oxidation product 14, which, however, was the main reaction product in the case of formylchromone. Frontier Molecular Orbital theory (FMO) predicted in all cases a $\mathrm{HOMO}_{(\mathrm{QDM})}-\mathrm{LUMO}_{\text {(chromone) }}$ controlled reaction. The observed regioselectivity was explained on account of the $\Delta c$ difference in absolute values of the $p_{z}$ orbital coefficients of the terminal reacting atoms in HOMO and LUMO, and also from the activation parameters calculated after locating the several transition states (TS) involved. The structure of all new compounds was confirmed by using 1D and 2D NMR data (COSY H-H, NOESY H-H, COSY $\mathrm{C}-\mathrm{H}$ and COLOC $\mathrm{C}-\mathrm{H}$ ), ms and elemental analysis. Full assignment of all ${ }^{1} \mathrm{H}$ and ${ }^{13} \mathrm{C}$ NMR chemical shifts has been unambiguously achieved.
\end{abstract}

Keywords: Carbazoles, chromones, Diels-Alder reactions, indazoles, pyrazoles, $o$-quinodimethanes

\section{Introduction}

Condensed heterocyclic systems are of considerable interest not only because of their potential biological activity but also because of their versatility as synthons in organic transformations.

${ }^{*}$ Corresponding author. Tel.: +30 2310997865 ; fax: +30 2310997679 
Concerning the chromone moiety, besides forming the basic nucleus of an entire class of natural products, i.e. flavones, ${ }^{1}$ it also forms the important component of pharmacophores of a large number of molecules of medicinal significance. ${ }^{2}$ Consequently, considerable attention is being devoted to isolation from natural resources, chemistry and synthesis of chromone derivatives, and evaluation of their biological activity with emphasis on their potential medicinal applications. $^{2-5}$ Moreover, chromone-fused heterocyclic derivatives have attracted a great deal of interest due to their wide applications in the field of pharmaceuticals. ${ }^{6}$ Because 3formylchromone has been extensively used in the formation of various heterocyclic systems, since its convenient synthesis was reported in the 1970s, the synthesis and reactivity of this versatile compound has been the subject of numerous reviews. ${ }^{5,7,8 a} 3$-Formylchromone represents a very reactive system due to the presence of an $\alpha, \beta$-unsaturated keto function, a conjugated second formyl group at $\mathrm{C}-3$ and a center at $\mathrm{C}-2$, which is very reactive towards Michael addition of nucleophiles with opening of the $\gamma$-pyrone ring followed by a new cyclization. Although 3-formylchromone has emerged as a valuable synthon for incorporation of the chromone moiety into a number of molecular frameworks, ${ }^{8}$ its synthetic utility is limited due to the facile opening of the chromone ring ${ }^{8,9}$ and strategies are being developed to circumvent it. ${ }^{10}$ On the other hand, indoles and pyrazoles have attracted considerable attention from both synthetic organic and medicinal chemists due to their biological activity covering a wide range of medicinal applications. ${ }^{6-9}$

Recently, a synthetic approach involving the reaction of 3-formylchromone with $O$ benzoquinodimethane, formed in situ by sulfur dioxide extraction from 1,3-dihydrobenzo$[c]$ thiophene and leading to benzo $[b]$ xanthones appeared in the literature. ${ }^{11 \mathrm{a}-\mathrm{b}}$ These results in combination with our continuous interest in the chemistry of $o$-quinodimethanes ${ }^{12}$ (o-QDMs) encouraged us to investigate further utilizations of formylchromones through reactions with heterocyclic $o$-QDMs, in order to obtain a variety of chromanoheterocycles, novel macrocycles having an intact chromone moiety at the periphery with potential biological applications. So, the possibility of incorporating the chromone moiety into the indole and also into the pyrazole nucleus was examined. Moreover, the study concerning the influence on the reaction regiochemistry by incorporating two different heterocyclic rings into the chromone moiety seemed of interest. In this work we wish to present a full report of our results. ${ }^{13}$

\section{Results and Discussion}

Our experiments considered the Diels-Alder reactions of 3-formylchromones 3a-3e with two heterocyclic $o$-QDMs, namely indole $o$-QDM 2, containing a five-membered ring with one nitrogen heteroatom, and pyrazole $o$-QDM 10, a heterocycle with two nitrogen heteroatoms in the five-membered ring.

Compounds $\mathbf{2}$ and $\mathbf{1 0}$ were generated in situ through reaction of sodium iodide to the appropriate dibromo-derivatives $\mathbf{1}$ and $\mathbf{9}$, respectively, which were prepared by reaction 
sequences reported in the literature. ${ }^{14,15}$ Initially, the Diels-Alder reaction of 3a with $o$-QDM 2 was carried out by the usual procedure, namely in refluxing DMF for $45 \mathrm{~min}$, whereupon from the reaction mixture after separation with column chromatography two fractions of products were isolated. The first fraction contained an inseparable on TLC mixture of the two diastereomers, which proved to be (see Structure Assignments section) the two possible trans diastereomers, 5a and 6a (12\% overall yield) in a 10:1 ratio. From this mixture a pure sample of compound $5 \mathbf{a}$ was obtained by recrystallization from $\mathrm{CH}_{2} \mathrm{Cl}_{2}-\mathrm{Et}_{2} \mathrm{O}$. The second fraction was shown to be a 2:1, inseparable on TLC mixture of the two possible cis diastereomers, 7a and 8a ( $7 \%$ overall yield, Scheme 1). Because the yields were considerably low, the reaction was repeated by modifying the reaction method. So, the reaction was repeated in boiling toluene for $10 \mathrm{~h}$, using 18-crown-6 ether as a phase transfer catalyst, whereupon substantial improvement was achieved and the same products were isolated in good yields. The 5a-6a mixture was isolated in $31 \%$ and the $7 \mathbf{a}-\mathbf{8 a}$ mixture in $26 \%$ overall yield, respectively. Therefore, the reactions with substituted 3 -formylchromones, $\mathbf{3 b}-\mathbf{3 e}$, were performed under the same conditions and the results are presented in Table 1. The reaction was also carried out in boiling benzene, where no reaction was observed and also in boiling xylene, whereupon in this higher temperature polymerization of the quinodimethane took place and no addition products were isolated. Attention should also be drawn to the fact that under the reaction conditions deformylation of the expected cycloadducts always occurred ${ }^{11,16}$ yielding the products 5-8.
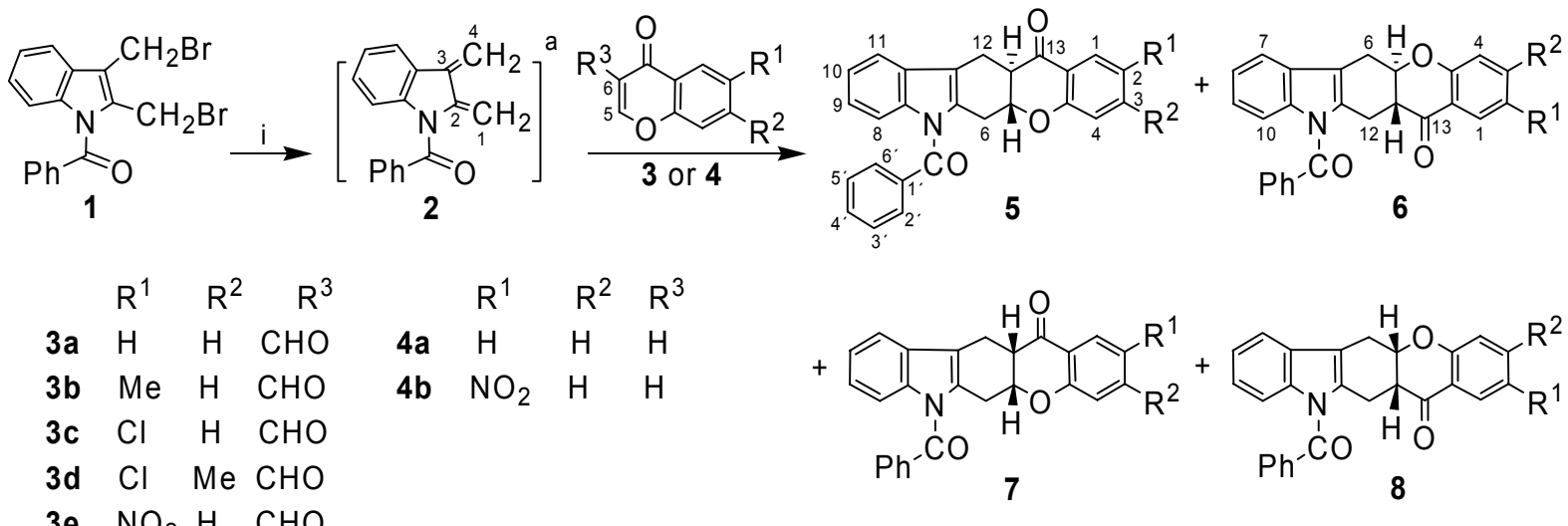

3e $\quad \mathrm{NO}_{2} \mathrm{H} \quad \mathrm{CHO}$

a The position numbering in the reactants $\mathbf{2}$ and $\mathbf{3}$ or $\mathbf{4}$ is arbitrary, used only for the computational study and the notation of transition states during the Diels-Alder reactions.

Scheme 1. Synthesis of indole $o$-QDM 2 and its reaction with some substituted chromenones 3 or 4. Reaction conditions: (i) NaI, 18-crown-6, toluene, reflux $10 \mathrm{~h}$ under $\mathrm{N}_{2}$. 

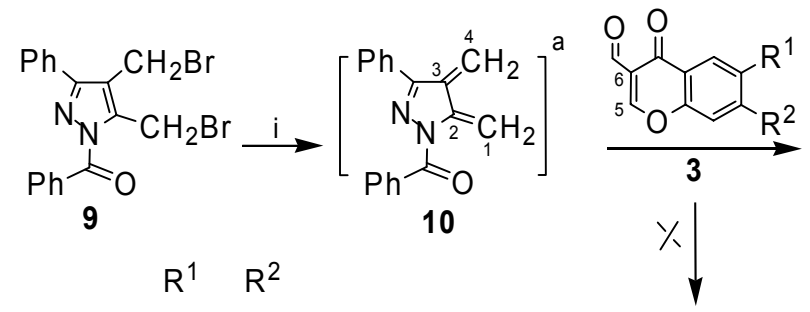

3a $\mathrm{H} \quad \mathrm{H}$

3b $\mathrm{Me} \mathrm{H}$

$3 c \quad \mathrm{Cl} \quad \mathrm{H}$

3d $\mathrm{Cl} \mathrm{Me}$

3e $\mathrm{NO}_{2} \mathrm{H}$

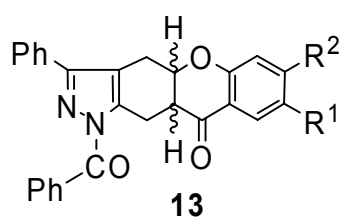

13
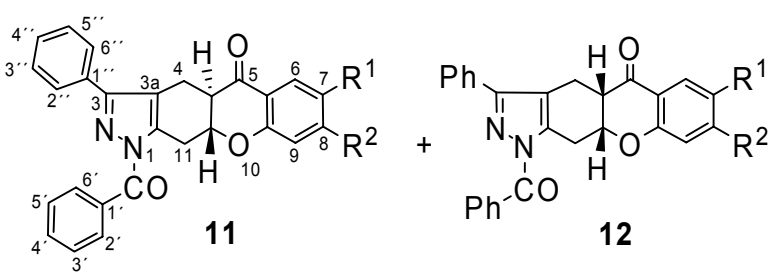

12
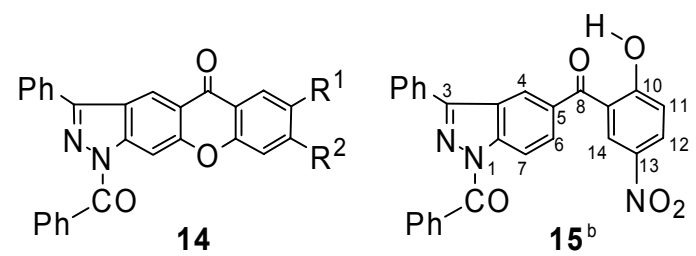

a Same as in Scheme 1. b The position numbering of 5-benzoyl group is arbitrary.

Scheme 2. Synthesis of pyrazole $o$-QDM 10 and its reaction with some substituted chromenones 3. Reaction conditions: (i) NaI, 18-crown-6, toluene, reflux 10 h under $\mathrm{N}_{2}$.

Table 1. Reaction products for compounds 5-8 and 11-12

\begin{tabular}{ccccc}
\hline & $\mathbf{5 + 6}$ & $\mathbf{7 + 8}$ & $\mathbf{1 1 + 1 2}$ & Dehydrogenated \\
\hline a & $31 \%(10: 1)$ & $26 \%(2: 1)$ & $20 \% \%^{\mathrm{a}}$ & $\mathbf{1 4} 35 \%$ \\
b & $3 \%(10: 1)$ & $44 \%(2.5: 1)$ & $42 \%(1: 2)$ & $\mathrm{b}$ \\
c & $29 \%(10: 1)$ & $34 \%(4: 1)$ & $51 \%(2: 3)$ & $\mathrm{b}$ \\
d & $23 \%(10: 1)$ & $32 \%(2.5: 1)$ & $48 \%(2: 3)$ & $\mathrm{b}$ \\
e & $27 \%(10: 1)$ & $59 \%(3: 1)$ & $31 \%(1: 2)$ & $\mathrm{b}$ \\
\hline
\end{tabular}

${ }^{\mathrm{a}}$ Only the cis isomer 12a is present. ${ }^{\mathrm{b}}$ In all cases compound $\mathbf{1 4}$ is present in $\sim 3 \%$.

Moreover, experiments involving reactions of chromones 4 with indole $o$-QDM 2, generated in situ through the action of sodium iodide on compound 1 either in dry refluxing DMF for 30 min or in dry refluxing toluene for $20 \mathrm{~h}$ in the presence of 18-crown-6 ether were carried out. However, in all cases low yields $(2-4 \%)$ of the corresponding mixture of cis and trans cycloaddition products, tetrahydrochromeno[2,3-b]carbazoles 5-8 were isolated, proving thus that the presence of the formyl group enhances considerably the dienophilicity of the chromone moiety (see Theoretical Calculations section). 


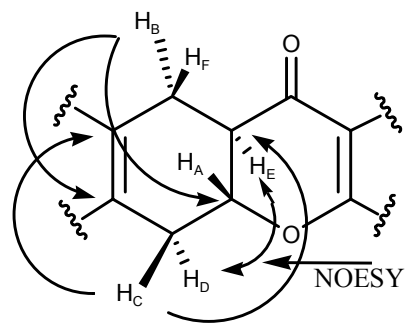

(a)

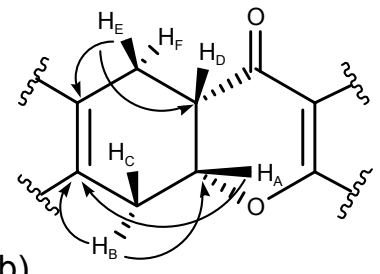

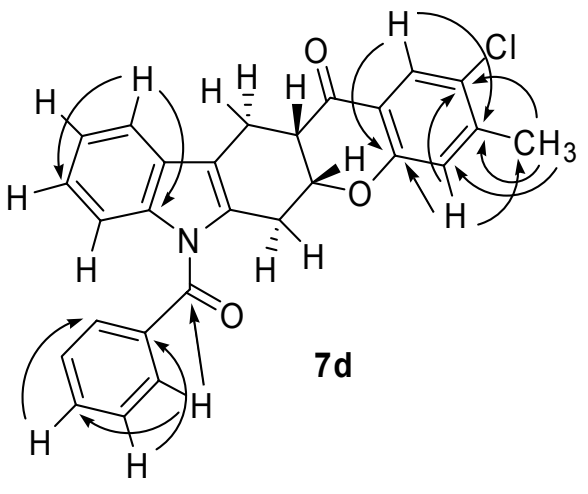

(c)

Figure 1. NOESY and COLOC correlations between protons and carbons in the saturated part of fused rings of compounds $\mathbf{5 a}$ (a) and $\mathbf{7 d}$ (b). (c) COLOC correlations in the aromatic rings in compound $7 \mathbf{d}$.

Next, the reaction of 3-formylchromones $\mathbf{3 a}-\mathbf{3 e}$ with pyrazole- $o$-quinodimethane $\mathbf{1 0}$ were studied in boiling toluene for $10 \mathrm{~h}$ using 18-crown-6 ether. It is remarkable that in this case the reaction was highly regioselective and mixtures of only two diastereomers $\mathbf{1 1 b}-\mathbf{1 1 e}$ and $\mathbf{1 2 b}$ 12e, were isolated in good yields by column chromatography, with the benzoyl group being always on the same side with the pyrane oxygen (Scheme 2, Table 1). The possible regio isomers 13 were never isolated, although small amounts less than $2 \%$ were formed, as was observed from ${ }^{1} \mathrm{H}$ nmr spectra of the crude reaction mixtures. In most cases this mixture was accompanied with small amounts (2-5\% yield) of the corresponding oxidation products 14 . However, in the case of 3a the oxidation product $\mathbf{1 4 a}$ was isolated as the main reaction product (35\% yield) together with 12a (20\% yield). Compound $\mathbf{1 4 a}$ most probably is formed by the dehydrogenation of the trans bridgehead hydrogens (4a-H and 10a-H). All formed products were again prone to deformylation under the reaction conditions. It is also notable that in the reactions studied in this work opening of the pyran ring was never observed. However, upon purification of 11e on prep. TLC cleavage of the pyran ring occurred resulting to the hydroxy derivative $\mathbf{1 5 .}$ 
(a)

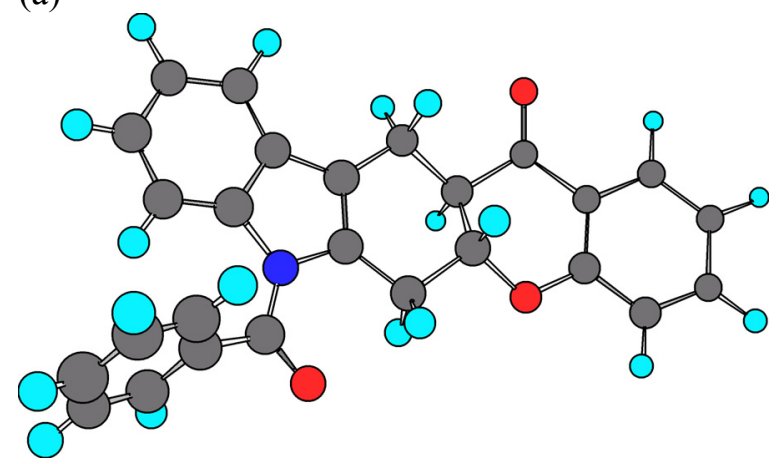

(b)

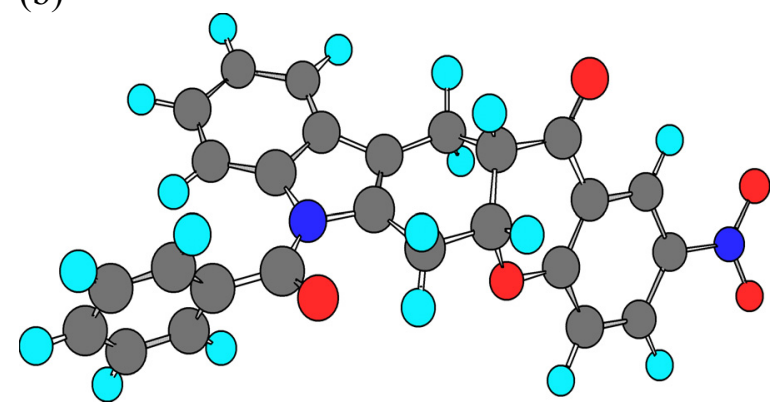

Figure 2. Minimum energy conformations of compounds 5a (a) and 7e (b) calculated by AM1 method.

\section{Structure assignments}

Concerning the stereochemistry of the cycloaddition products the structure of $\mathbf{5 a}$ will be analysed. This structure was deduced on account of the following data. For the saturated protons $\mathrm{H}_{\mathrm{A}}-\mathrm{H}_{\mathrm{F}}$ (Figure 1a) one proton multiplets at 4.622, 3.499, 3.460, 3.306, 3.102 and $2.824 \delta$ were observed in the ${ }^{1} \mathrm{H}$ nmr spectrum, correspondingly. The most downfield multiplet at $4.622 \delta$ was attributed to the $\mathrm{H}_{\mathrm{A}}$ proton next to the chromone oxygen. This proton shows COSY correlations with the $3.102 \delta$ proton and also with the 3.460 and $3.306 \delta$ protons belonging to the $32.07 \mathrm{ppm}$ carbon (C-6), whereas the $3.102 \delta$ proton shows correlations with the $4.622 \delta$ proton and also with the 3.499 and $2.824 \delta$ protons belonging to the $19.82 \mathrm{ppm}$ carbon $(\mathrm{C}-12)$. In this way the arrangement of the methylene groups was deduced.

Moreover, from the coupling constants of $J_{A D}=9.6 \mathrm{~Hz}, J_{A E}=13.3 \mathrm{~Hz}$ and $J_{E F}=10.8 \mathrm{~Hz}$ the conclusion of an axial-axial (trans) configuration between these protons could be drawn, whereas the coupling constants of $J_{A C}=6.1 \mathrm{~Hz} \kappa \alpha 1 J_{B E}=6.1 \mathrm{~Hz}$ indicated an axial-equatorial configuration of these protons. ${ }^{17}$ On the other hand, COLOC correlations between $\mathrm{H}_{\mathrm{C}}$ with carbons at $45.67(\mathrm{C}-12 \mathrm{a})$ and $115.87 \mathrm{ppm}(\mathrm{C}-11 \mathrm{~b})$, and between $\mathrm{H}_{\mathrm{B}}$ with carbons at 131.55 (C6a) and $77.72 \mathrm{ppm}$ (C-5a) indicated that these protons occupy equatorial positions in the cyclohexene ring justifying thus their favorable dihedral angles. The more downfield shift of $\mathrm{H}_{\mathrm{C}}$ compared to $\mathrm{H}_{\mathrm{D}}$ and of $\mathrm{H}_{\mathrm{B}}$ compared to $\mathrm{H}_{\mathrm{F}}$ can be attributed to the fact that equatorial protons in cyclohexane rings resonate at about $0.5 \mathrm{ppm}$ more downfield than their axial counterparts and also to a small extent to their vicinity with the $\mathrm{NCOPh}$ and pyrane carbonyls, the $\mathrm{NCOPh}$ group causing also a slight broadening to the $\mathrm{H}_{\mathrm{C}}$ multiplet. Moreover, the homoallylic coupling constant $J_{D F}$ between the C-6 and C-12 axial protons varies between 2.5 to $3.3 \mathrm{~Hz}$, whereas in the case of axial-equatorial protons is $\sim 1.7 \mathrm{~Hz}$. The minimized energy conformation of compound 5a calculated by AM1 is depicted in Figure 2a. To the minor component the 6a structure was deduced. 
Concerning the two cis addition products 7 and $\mathbf{8}$ the structure of 7e was analysed based on the following data. The chemical shift of the carbon at $76.58 \mathrm{ppm}$ with its proton $\mathrm{H}_{\mathrm{A}}$ resonating at $5.168 \delta$ reveals its neighborhood to the ether oxygen. This proton shows a ddd multiplet with smaller coupling with its neighbors $\left(J_{A B}=4.5 \mathrm{~Hz}, J_{A C}=4.2 \mathrm{~Hz}\right.$ and $J_{A D}=2.7 \mathrm{~Hz}$, Figure $\left.1 \mathrm{~b}\right)$. The small coupling constants reveal a chair instead of a boat conformation of the cyclohexene ring, $\mathrm{H}_{\mathrm{A}}$ having an equatorial configuration. This configuration is also in agreement with the fact that $\mathrm{H}_{\mathrm{A}}$ shows COLOC correlation with the quaternary carbon C-6a at $131.33 \mathrm{ppm}$. On the other hand, $\mathrm{H}_{\mathrm{D}}$ shows a ddd multiplet at $3.222 \delta$ with $J_{D F}=9.4 \mathrm{~Hz}, J_{D E}=6.7 \mathrm{~Hz}$ and $J_{A D}=2.7 \mathrm{~Hz}$ and no COLOC correlation with $\mathrm{C}-11 \mathrm{~b}$. This conformation is more flexible than that of the trans adduct 5; as a result, the methylene protons $\mathrm{H}_{\mathrm{B}}, \mathrm{H}_{\mathrm{C}}$ at 6- and $\mathrm{H}_{\mathrm{E}}, \mathrm{H}_{\mathrm{F}}$ at 12-positions are not diversified in their chemical shifts as it happens in 5. All COLOC correlations in the aromatic rings are depicted in Figure 1c. The structure which is in agreement with these data most probably has the chromone moiety almost perpendicular to the indole-cyclohexene moiety (Figure 2b).

\section{Theoretical calculations}

In order to investigate the reactivity of the reacting species and the regioselectivity of the products 5-8 and 11-12 we have studied the frontier molecular orbital (FMO) interactions of the reactants and the transition structures (TS) of the intermediates involved. Full geometry optimizations were carried out for $o$-QDMs $\mathbf{2}$ and $\mathbf{1 0}$ and chromones $\mathbf{3}$ and $\mathbf{4}$ as well as for the possible adducts and the corresponding transition structures (TS1-TS12) at the AM1 level of theory (Figures 3, 4 and 5). For each located TS after complete optimization with the keywords LET and PRECISE only one imaginary frequency was calculated assigned to the shorter new forming bond. ${ }^{18}$ The activation energy of almost any reaction is influenced by the polarity of the solvent used. In the present case, since in all studied reactions the conditions are similar, the solvent effects can be ignored, as long as the differences of activation parameters are calculated. In Table 2 the calculated HOMO-LUMO energies (eigenvalues) and the orbital coefficients (eigenvectors) for the atoms of all compounds involved in the [4+2] cycloaddition reaction are presented. According to FMO interactions the energy difference between the two orbitals involved is essential, the smaller the better, so the reaction of the indolo-o-QDMs 2 and pyrazolo- $o$-QDMs 10 with 3-formylchromones $\mathbf{3}$ and with chromones $\mathbf{4}$ are predicted to be $\mathrm{HOMO}_{(\mathrm{QDM})}-\mathrm{LUMO}_{\text {(chromone) }}$ controlled (Figure 6a). The opposite attacking process is predicted to be energetically disfavored by 29 to $81 \mathrm{kcal} / \mathrm{mol}$ (Table 3 ).

Examining the MO coefficients in Table 2 the first attacking position of chromone can be predicted. In all cases the chromone position 5 (see Schemes 1 and 2 for the arbitrary numbering) has the larger coefficient and consequently the new forming bond begins there. 


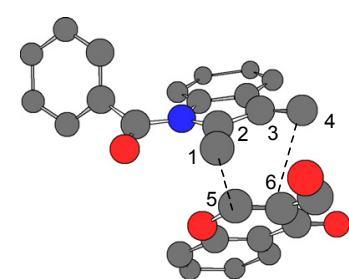

$3 a$

TS1

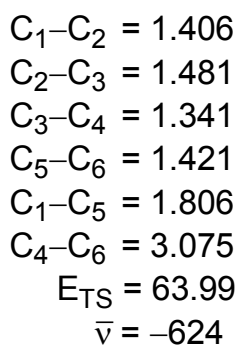

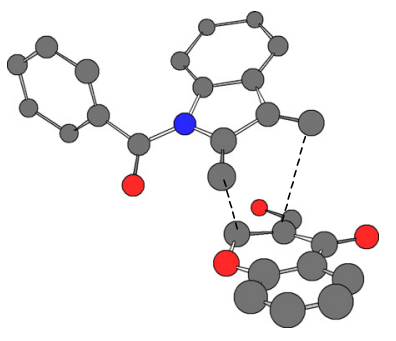

TS2

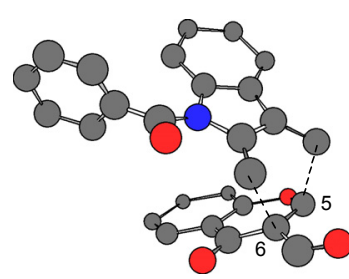

TS3

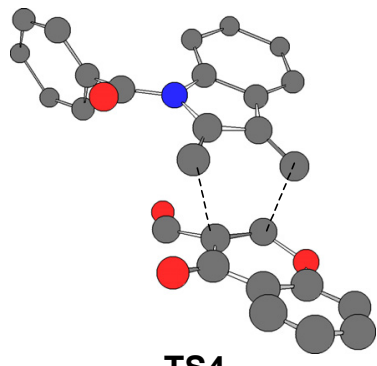

TS4

Figure 3. Transition structures optimized at AM1 level for the interaction of $o$-QDM 2 with chromone 3a for endo or exo approaching leading to product 7 (TS1, TS2) and 8 (TS3, TS4). The values of bond lengths involved in the new cyclohexene ring along with the heats of formation of the activated complex at TS and the vibrating frequency of the shorter new forming bond at $383 \mathrm{~K}$ are given. All bond lengths are in angstroms $(\AA)$ and energies in $\mathrm{kcal} / \mathrm{mol}$. For the numbering of reacting atoms see Scheme 1.

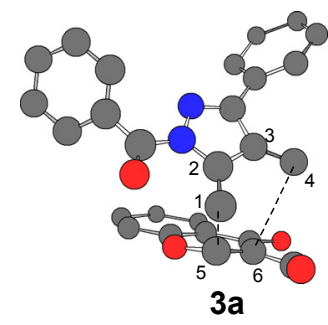

TS5

$\mathrm{C}_{1}-\mathrm{C}_{2}=1.401$

$\mathrm{C}_{2}-\mathrm{C}_{3}=1.477$

$\mathrm{C}_{3}-\mathrm{C}_{4}=1.340$

$\mathrm{C}_{5}-\mathrm{C}_{6}=1.420$

$\mathrm{C}_{1}-\mathrm{C}_{5}=1.817$

$\mathrm{C}_{4}-\mathrm{C}_{6}=3.079$

$\mathrm{E}_{\mathrm{TS}}=105.39$

$\bar{v}=-653$

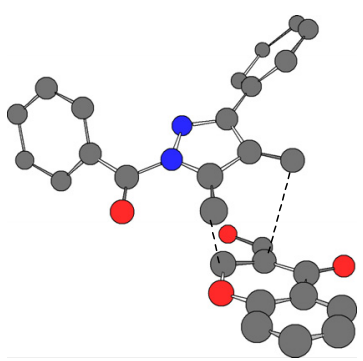

TS6

$\mathrm{C}_{1}-\mathrm{C}_{2}=1.402$

$\mathrm{C}_{2}-\mathrm{C}_{3}=1.478$

$\mathrm{C}_{3}-\mathrm{C}_{4}=1.339$

$\mathrm{C}_{5}-\mathrm{C}_{6}=1.420$

$\mathrm{C}_{1}-\mathrm{C}_{5}=1.816$

$\mathrm{C}_{4}-\mathrm{C}_{6}=3.130$

$\mathrm{E}_{\mathrm{TS}}=105.55$

$\bar{v}=-663$

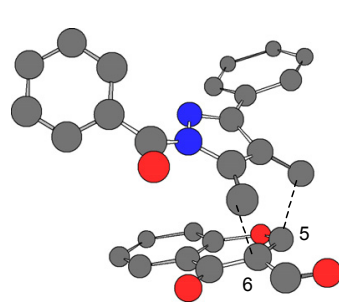

TS7

$\mathrm{C}_{1}-\mathrm{C}_{2}=1.378$

$\mathrm{C}_{2}-\mathrm{C}_{3}=1.446$

$\mathrm{C}_{3}-\mathrm{C}_{4}=1.382$

$\mathrm{C}_{5}-\mathrm{C}_{6}=1.414$

$\mathrm{C}_{1}-\mathrm{C}_{6}=2.295$

$\mathrm{C}_{4}-\mathrm{C}_{5}=2.028$

$\mathrm{E}_{\mathrm{TS}}=108.41$

$\bar{v}=-816$

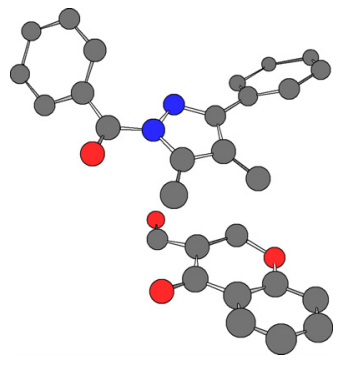

TS8

$\mathrm{C}_{1}-\mathrm{C}_{2}=1.379$

$\mathrm{C}_{2}-\mathrm{C}_{3}=1.445$

$\mathrm{C}_{3}-\mathrm{C}_{4}=1.381$

$\mathrm{C}_{5}-\mathrm{C}_{6}=1.415$

$\mathrm{C}_{1}-\mathrm{C}_{6}=2.272$

$\mathrm{C}_{4}-\mathrm{C}_{5}=2.037$

$\mathrm{E}_{\mathrm{TS}}=108.33$

$\bar{v}=-832$

Figure 4. Transition structures for the interaction of $o-\mathrm{QDM} 10$ with chromone 3a for endo or exo approaching leading to product 12 (TS5, TS6) and 13 (TS7, TS8). For the numbering of reacting atoms see Scheme 2. 


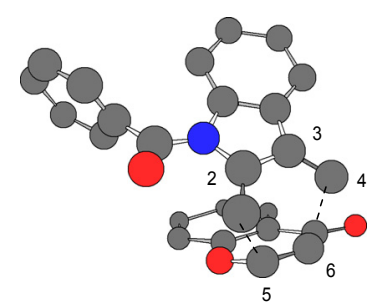

$4 a$

TS9

$$
\begin{aligned}
\mathrm{C}_{1}-\mathrm{C}_{2} & =1.392 \\
\mathrm{C}_{2}-\mathrm{C}_{3} & =1.445 \\
\mathrm{C}_{3}-\mathrm{C}_{4} & =1.374 \\
\mathrm{C}_{5}-\mathrm{C}_{6} & =1.405 \\
\mathrm{C}_{1}-\mathrm{C}_{5} & =2.065 \\
\mathrm{C}_{4}-\mathrm{C}_{6} & =2.200 \\
\mathrm{E}_{\mathrm{TS}} & =97.00 \\
\bar{v} & =-869
\end{aligned}
$$

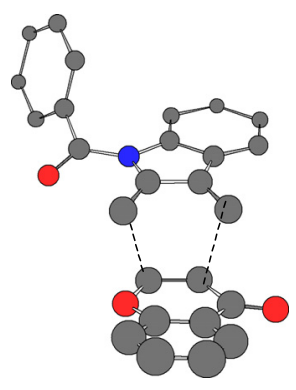

TS10

$$
\begin{aligned}
C_{1}-C_{2} & =1.390 \\
C_{2}-C_{3} & =1.444 \\
C_{3}-C_{4} & =1.376 \\
C_{5}-C_{6} & =1.406 \\
C_{1}-C_{5} & =2.083 \\
C_{4}-C_{6} & =2.158 \\
E_{T S} & =95.13 \\
\bar{v} & =-896
\end{aligned}
$$

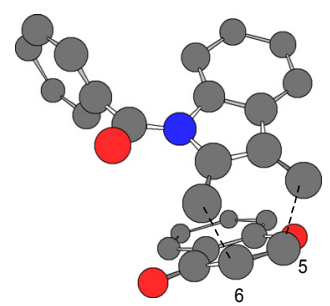

TS11

$\mathrm{C}_{1}-\mathrm{C}_{2}=1.385$

$\mathrm{C}_{2}-\mathrm{C}_{3}=1.442$

$\mathrm{C}_{3}-\mathrm{C}_{4}=1.381$

$\mathrm{C}_{5}-\mathrm{C}_{6}=1.404$

$\mathrm{C}_{1}-\mathrm{C}_{6}=2.174$

$\mathrm{C}_{4}-\mathrm{C}_{5}=2.088$

$\mathrm{E}_{\mathrm{TS}}=98.88$

$\bar{v}=-894$

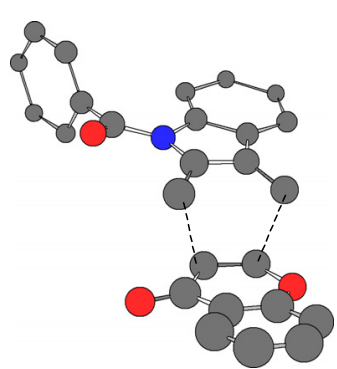

TS12

$\mathrm{C}_{1}-\mathrm{C}_{2}=1.387$

$\mathrm{C}_{2}-\mathrm{C}_{3}=1.441$

$\mathrm{C}_{3}-\mathrm{C}_{4}=1.380$

$\mathrm{C}_{5}-\mathrm{C}_{6}=1.404$

$\mathrm{C}_{1}-\mathrm{C}_{6}=2.151$

$\mathrm{C}_{4}-\mathrm{C}_{5}=2.094$

$\mathrm{E}_{\mathrm{TS}}=96.63$

$\bar{v}=-915$

Figure 5. Transition structures for the interaction of $o$-QDM 2 with chromone 4 a for endo or exo approaching leading to product 7 (TS9, TS10) and 8 (TS11, TS12). For the numbering of reacting atoms see Scheme 1.

(a)

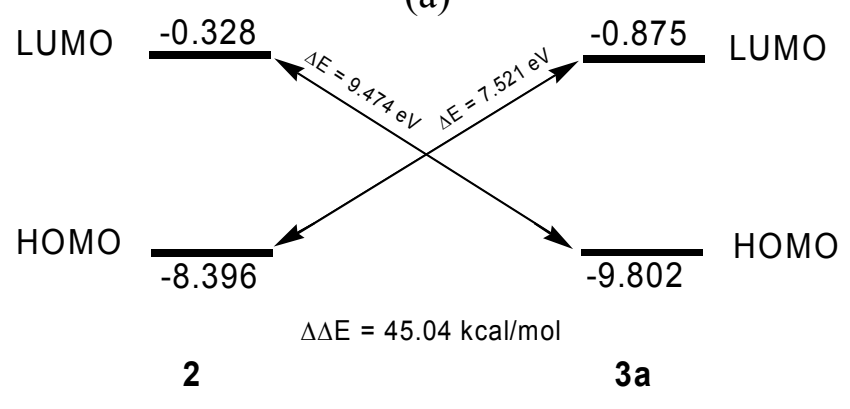

(b)

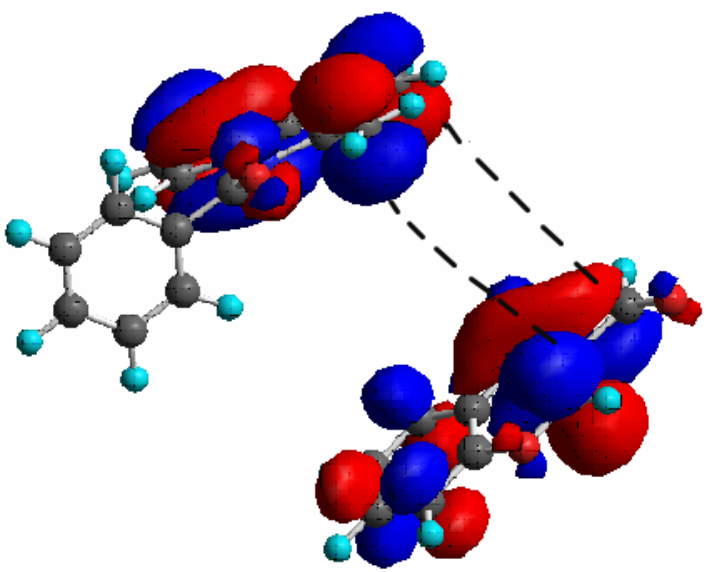

Figure 6. (a) Molecular orbital correlation diagram for the interaction of $o$-QDM 2 with chromone 3a in the endo approaching TS1 calculated by AM1. (b) HOMO-LUMO interaction of $\mathbf{2}$ and $\mathbf{3 a}$ in the endo transition state TS1.

In order to examine the regioselectivity of the reactions both the coefficients of the reacting $\mathrm{MO}$ and the energetically favored TS were examined. The reactions can proceed either by endo or by exo approach of the reacting species. So, all the possible TS were located and the heats of formation $E_{\mathrm{TS}}{ }^{\#}$ at the reaction temperature $\left(110{ }^{\circ} \mathrm{C}, 383 \mathrm{~K}\right)$ were calculated.

According to FMO theory the reaction progress depends on the orbital overlapping in the TS, 
the larger overlap giving the better yield. In asymmetric $\pi$ systems, as in our case, the regioselectivity depends on the difference of size of the mutual overlapping orbitals as well as on steric effects, which affect the easy proximity of the reacting species. As a measure for the first factor the difference of the vectors of $p_{z}$ orbitals can be used, whereas for the steric effects the energy of formation of the transition structure (or the free energy of activation $\Delta \mathrm{G}^{\#}$ ) is a good tool. As a result, in the transition state complex the corresponding bond is always shorter. This means that even if the reaction is believed to be concerted, it is slightly asynchronous. In favor of this statement is the fact that both cis and trans isomeric products are present in the crude reaction mixture, exluding the isomerisation induced by the silica gel. In Table $2 \Delta \mathrm{c}$ represents the difference in absolute values of the $\mathrm{p}_{z}$ orbital coefficients of terminal reacting atoms. The bigger the difference the better regioselectivity can be achieved. So, the fact that the $\Delta \mathrm{c}$ value (Table 2) of the reacting HOMO of the pyrazole $o$-QDM 10 is almost double than the corresponding of indole $o$-QDM 2 is in agreement with the experimental results (Table 1), where in the case of $\mathbf{1 0}$ only one regio isomer was isolated.

Table 2. Calculated HOMO-LUMO energies (eV) and orbital coefficients (eigenvectors) for the atoms involved in new bond formations ${ }^{\mathrm{a}}$ for the reaction of $o$-QDMs $\mathbf{2}$ and $\mathbf{1 0}$ with chromones 3 and 4 (in gas phase at $298 \mathrm{~K}, \mathrm{AM} 1$ )

\begin{tabular}{lcclllll}
\hline Comp. & HOMO & LUMO & $\Delta$ c & Comp. & HOMO & LUMO & $\Delta c$ \\
\hline $\mathbf{2}$ & $-8.396^{\mathrm{b}}$ & -0.328 & & $\mathbf{1 0}$ & -8.602 & -0.580 & \\
C-1 & $0.4242^{\mathrm{c}}$ & 0.2708 & $0.0596^{\mathrm{d}}$ & C-1 & -0.4610 & 0.2793 & 0.0996 \\
C-2 & 0.2163 & -0.1508 & & C-2 & -0.2437 & -0.1473 & \\
C-3 & -0.1838 & -0.2996 & & C-3 & 0.1823 & -0.2631 & \\
C-4 & -0.3646 & 0.4812 & & C-4 & 0.3614 & 0.4509 & \\
3a & -9.802 & -0.875 & & $\mathbf{3 e}$ & -10.531 & -1.722 & \\
C-5 & 0.1302 & -0.5722 & $0.2972^{\mathrm{e}}$ & C-5 & 0.2054 & -0.2543 & 0.0255 \\
C-6 & 0.3719 & 0.2750 & & C-8 & 0.4386 & 0.2288 & \\
3b & -9.581 & -0.837 & & $\mathbf{4 a}$ & -9.472 & -0.547 & \\
C-5 & -0.0810 & -0.5896 & 0.3000 & C-5 & 0.1572 & -0.3379 & 0.2062 \\
C-6 & -0.3066 & 0.2896 & & C-6 & 0.3633 & 0.1317 & \\
3c & -9.765 & -1.044 & & $\mathbf{4 b}$ & -10.241 & -1.174 & \\
C-5 & 0.0839 & 0.5229 & 0.2837 & C-5 & 0.2252 & -0.3357 & 0.1741 \\
C-6 & 0.3003 & -0.2392 & & C-6 & 0.4210 & 0.1616 & \\
3d & -9.700 & -1.003 & & & & & \\
C-5 & -0.0723 & -0.4820 & 0.2769 & & & & \\
C-6 & -0.2833 & 0.2051 & & & & & \\
\hline
\end{tabular}

${ }^{\mathrm{a}}$ For atom numbering of the diene moieties and chromones see Schemes 1 and $2 .{ }^{\mathrm{b}} \mathrm{HOMO}-$ LUMO energies (eigenvalues, in $\mathrm{eV}$ ). ${ }^{\mathrm{c}}$ Orbital coefficients (eigenvectors). ${ }^{\mathrm{d}} \Delta \mathrm{c}$ is the difference in absolute values of the $p_{z}$ orbital coefficients of the terminal reacting atoms $1-4$ (HOMO). ${ }^{e} \mathrm{As}$ above, for 5-6 (LUMO). ${ }^{\mathrm{f}} N$-LUMO. 
Table 3. Energy differences for the various HOMO-LUMO interactions between quinodimethanes (2 and 10) and chromones $\mathbf{3 a}-\mathbf{e}$ and $\mathbf{4 a}-\mathbf{b}$ (in gas phase at $298^{\circ} \mathrm{K}$, AM1)

\begin{tabular}{lrrrrrrrr}
\hline \multicolumn{1}{l}{ Reaction } & \multicolumn{3}{c}{ with 2 } & \multicolumn{3}{c}{ with 10 } \\
\hline & HOMO & LUMO & $\Delta E\left(\mathrm{~L}_{\text {chr }}\right)^{\mathrm{a}}$ & $\Delta E\left(\mathrm{~L}_{\text {qdm }}\right)$ & $\Delta \Delta E^{\mathrm{b}}$ & $\Delta E\left(\mathrm{~L}_{\text {chr }}\right)$ & $\Delta E\left(\mathrm{H}_{\text {chr }}\right)$ & $\Delta \Delta E$ \\
\hline 3a & -9.802 & -0.875 & 7.521 & 9.474 & 45.04 & 7.727 & 9.222 & 34.47 \\
3b & -9.581 & -0.837 & 7.559 & 9.253 & 39.06 & 7.765 & 9.001 & 28.50 \\
3c & -9.765 & -1.044 & 7.352 & 9.437 & 48.08 & 7.558 & 9.185 & 37.52 \\
3d & -9.700 & -1.003 & 7.393 & 9.372 & 45.64 & 7.599 & 9.120 & 35.07 \\
3e & -10.531 & -1.722 & 6.674 & 10.203 & 81.38 & 6.880 & 9.951 & 70.82 \\
4a & -9.472 & -0.547 & 7.849 & 9.144 & 29.86 & 8.055 & 8.892 & 19.30 \\
4b & -10.241 & $-1.174^{\mathrm{c}}$ & 7.222 & 9.913 & 62.05 & 7.428 & 9.661 & 51.49 \\
\hline
\end{tabular}

${ }^{\mathrm{a}} \Delta E\left(\mathrm{~L}_{\text {chr }}\right)=E\left(\mathrm{LUMO}_{\text {chromone }}\right)-E\left(\mathrm{HOMO}_{\mathrm{qdm}}\right) ; \Delta E\left(\mathrm{~L}_{\mathrm{qdm}}\right)=E\left(\mathrm{LUMO}_{\mathrm{qdm}}\right)-E\left(\mathrm{HOMO}_{\text {chromone }}\right)$, (in $\mathrm{eV} / \mathrm{mol}) .{ }^{\mathrm{b}} \Delta \Delta E=\Delta E\left(\mathrm{~L}_{\mathrm{qdm}}\right)-\Delta E\left(\mathrm{~L}_{\text {chromone }}\right),($ in $\mathrm{kcal} / \mathrm{mol}) .{ }^{\mathrm{c}} N-\mathrm{LUMO}$.

The activation energy factor is also very important. When two possible TS can be involved, the one with the lower activation energy is considered to be kinetically favored. In Tables 4 and 5 the calculated ratio of the intermediate adducts, before formyl elimination, resulting from endo/exo approach ${ }^{19}$ of the reacting species is shown in the last column. Since these approaches afford the same products the comparison has only theoretical interest. The selected, from Tables 4 and 5, TS with the lower activation energies corresponding to the favored approach for each one of the studied reactions are given in Table 6. The comparison of these activation parameters showed that in all cases products $\mathbf{7}$ and $\mathbf{1 2}$ are predicted to be favored over $\mathbf{8}$ and $\mathbf{1 3}$, respectively. In Figure $6 \mathrm{~b}$ the HOMO-LUMO interaction of compounds $\mathbf{2}$ and $\mathbf{3 a}$ in the endo approaching transition state TS1 is depicted. All isolated products resulted after deformylation of the primarily formed cycloaddition products. By adding up the yields given in Table 1 for $\mathbf{5 + 7}$, and $\mathbf{6}+\mathbf{8}$ a ratio of approximately $13: 2$ (or $86: 14 \%$ ) is obtained, a value very close to the theoretical prediction of 97:3 given in Table 6, calculated in vacuo without solvent effects. On the other hand, products $\mathbf{1 2}$ are predicted to be favored over $\mathbf{1 3}$ in a ratio of 99:1, which is practically the same with the one found experimentally (98:2) by ${ }^{1} \mathrm{H} \mathrm{nmr}$ of the crude reaction mixture. 
Table 4. Calculated energies of formation $\Delta H_{f}^{\mathrm{a}}$ and activation parameters for the endo and exo transition structures and corresponding adducts for the reactions of $o$-QDMs 2 with chromones 3a-e and 4a-b leading: (a) to compounds 7 and (b) to compounds 8 (in gas phase, $383{ }^{\circ} \mathrm{K}$, AM1) ${ }^{\mathrm{b}}$

\begin{tabular}{|c|c|c|c|c|c|c|c|c|c|c|}
\hline \multirow[t]{2}{*}{ (a) } & \multicolumn{5}{|c|}{ Endo approach } & \multicolumn{5}{|c|}{ Exo approach } \\
\hline & $\Sigma \Delta H_{\mathrm{f}(\mathrm{r})}^{\mathrm{c}}$ & $\Delta H_{\mathrm{f}(\mathrm{p})}$ & $\Delta H^{o \mathrm{~d}}$ & $E_{\mathrm{TS}}^{\mathrm{e}}$ & $\Delta H_{(\text {endo) }}^{\#}{ }^{\mathrm{f}}$ & $E_{\mathrm{TS}}$ & $\Delta H_{(\text {(xo) }}^{\#}$ & $\Delta \Delta H^{\# \mathrm{~g}, \mathrm{~h}}$ & $\begin{array}{l}\mathrm{C}_{\text {endo }} \\
\mathrm{C}_{\text {exo }} \mathrm{i} \\
\end{array}$ & $\begin{array}{l}\mathrm{C}_{\text {endol }} \\
\mathrm{C}_{\text {exo }}{ }^{j} \\
\end{array}$ \\
\hline $3 a$ & 36.63 & 2.99 & -33.64 & 63.99 & 27.36 & 64.07 & 27.44 & -0.08 & 1.111 & $53 / 47$ \\
\hline $3 \mathbf{b}$ & 29.42 & -4.07 & -33.49 & 56.98 & 27.56 & 57.05 & 27.63 & -0.07 & 1.096 & $52 / 48$ \\
\hline $3 c$ & 30.99 & -2.93 & -33.92 & 57.42 & 26.43 & 60.59 & 29.60 & -3.17 & 64.43 & $98 / 2$ \\
\hline $3 d$ & 24.31 & -9.60 & -33.91 & 53.81 & 29.50 & 51.09 & 26.78 & 2.72 & 0.028 & $3 / 97$ \\
\hline $3 e$ & 43.64 & 8.59 & -35.05 & 67.69 & 24.05 & 67.89 & 24.25 & -0.20 & 1.301 & $57 / 43$ \\
\hline $4 a$ & 68.11 & 24.48 & -43.63 & 97.00 & 28.89 & 95.13 & 27.02 & 1.87 & 0.086 & $8 / 92$ \\
\hline $4 b$ & 74.03 & 29.19 & -44.84 & 101.33 & 27.30 & 99.93 & 25.90 & 1.40 & 0.159 & $14 / 86$ \\
\hline \multirow[t]{2}{*}{ (b) } & \multicolumn{5}{|c|}{ Endo approach } & \multicolumn{5}{|c|}{ Exo approach } \\
\hline & $\Sigma \Delta H_{\mathrm{f}(\mathrm{r})}{ }^{\mathrm{c}}$ & $\Delta H_{\mathrm{f}(\mathrm{p})}$ & $\Delta H^{o \mathrm{~d}}$ & $E_{\mathrm{TS}}{ }^{\mathrm{e}}$ & $\Delta H_{(\text {endo })}^{\#}$ & $E_{\mathrm{TS}}$ & $\Delta H_{(\text {exo })}^{\#}$ & $\begin{array}{r}\Delta \Delta H^{\#} \\
\mathrm{~g}, \mathrm{~h}\end{array}$ & $\begin{array}{l}\mathrm{C}_{\text {endol }} \\
\mathrm{C}_{\text {exo }} \mathrm{i} \\
\end{array}$ & $\begin{array}{l}\mathrm{C}_{\text {endol }} \\
\mathrm{C}_{\text {exo }}{ }^{\mathrm{j}} \\
\end{array}$ \\
\hline $3 \mathbf{a}$ & 36.63 & 2.89 & -33.74 & 67.30 & 30.67 & 66.68 & 30.05 & 0.62 & 0.443 & $31 / 69$ \\
\hline $3 \mathbf{b}$ & 29.42 & -4.14 & -33.56 & 60.13 & 30.71 & 59.61 & 30.19 & 0.52 & 0.505 & $34 / 66$ \\
\hline $3 c$ & 30.99 & -3.14 & -34.13 & 60.93 & 29.94 & 60.63 & 29.64 & 0.30 & 0.674 & $40 / 60$ \\
\hline 3d & 24.31 & -9.79 & -35.58 & 54.41 & 30.10 & 54.05 & 29.74 & 0.36 & 0.623 & $38 / 62$ \\
\hline $3 e$ & 43.64 & 8.06 & -35.58 & 71.59 & 27.95 & 72.00 & 28.36 & -0.41 & 1.714 & $63 / 37$ \\
\hline $4 a$ & 68.11 & 24.05 & -44.06 & 98.88 & 30.77 & 96.63 & 28.52 & 2.25 & 0.052 & $5 / 95$ \\
\hline $4 b$ & 74.03 & 28.80 & -45.23 & 102.80 & 28.77 & 101.62 & 27.59 & 1.18 & 0.212 & $18 / 82$ \\
\hline
\end{tabular}

${ }^{\mathrm{a}} \Delta H_{f}$ for the reactants $\left(\right.$ at $383{ }^{\circ} \mathrm{K}$, in $\left.\mathrm{kcal} / \mathrm{mol}\right): \mathbf{2}=87.17 ; \mathbf{3 a}=-50.54 ; \mathbf{3} \mathbf{b}=-57.75 ; \mathbf{3} \mathbf{c}=-56.18$; $\mathbf{3 d}=-62.86 ; \mathbf{3 e}=-43.53 ; \mathbf{4} \mathbf{a}=-19.06 ; \mathbf{4} \mathbf{b}=-13.14 .{ }^{\mathrm{b}} \quad$ The boiling temperature of toluene. ${ }^{\mathrm{c}}$ $\Sigma \Delta H_{\mathrm{f}(\mathrm{r})}=\Delta H_{\mathrm{f}(\mathrm{chr})}+\Delta H_{\mathrm{f}(\mathrm{QDM})},(\mathrm{p}=$ products, $\mathrm{r}=$ reactants, $\mathrm{chr}=$ chromone $) .{ }^{\mathrm{d}} \Delta H^{\mathrm{o}}=\Delta H_{f(\mathrm{p})}-$ $\Sigma \Delta H_{\mathrm{f}(\mathrm{r})}{ }^{\mathrm{e}} E_{\mathrm{TS}}$ is the calculated $\Delta \mathrm{H}_{\mathrm{f}}$ for the transition state. ${ }^{\mathrm{f}} \Delta H^{\#}=E_{\mathrm{TS}}-\Sigma \Delta H_{\mathrm{f}(\mathrm{r})} \cdot{ }^{\mathrm{g}} \Delta \Delta H^{\#}=$ $\Delta H^{\#}{ }_{(e n d o)}-\Delta H^{\#}{ }_{(\text {exo })}$ is the relative activation energy. ${ }^{\mathrm{h}}$ A negative value means a more stable TS for endo approach, the corresponding adduct being kinetically favored. ${ }^{\mathrm{i}} \mathrm{C}_{\text {endo }} / \mathrm{C}_{\text {exo }}$ is the relative calculated ratio of products 7 derived from endo versus that of exo approach by the Boltzmann equation for equilibrium distribution. ${ }^{\mathrm{j}} \mathrm{C}_{\text {endo }} / \mathrm{C}_{\text {exo }}$ is the corresponding calculated $\%$ ratio of products. 
Table 5. Calculated energies of formation $\Delta H_{f}^{\mathrm{a}}$ and activation parameters for the endo and exo transition structures and corresponding adducts for the reactions of $o$-QDMs $\mathbf{1 0}$ with chromones 3a-e leading: (a) to compounds $\mathbf{1 2}$ and (b) to compounds $\mathbf{1 3}$ (in gas phase, $\left.383{ }^{\circ} \mathrm{K}, \mathrm{AM} 1\right)^{\mathrm{b}}$

\begin{tabular}{|c|c|c|c|c|c|c|c|c|c|c|}
\hline \multirow[t]{2}{*}{ (a) } & \multicolumn{5}{|c|}{ Endo approach } & \multicolumn{5}{|c|}{ Exo approach } \\
\hline & $\Sigma \Delta H_{\mathrm{f}(\mathrm{r})}^{\mathrm{c}}$ & $\Delta H_{\mathrm{f}(\mathrm{p})}$ & $\Delta H^{o \mathrm{~d}}$ & $E_{\mathrm{TS}}^{\mathrm{e}}$ & $\Delta H_{(\text {endo) }}^{\#}{ }^{\mathrm{f}}$ & $E_{\mathrm{TS}}$ & $\Delta H_{(\text {exo })}^{\#}$ & $\Delta \Delta H^{\# \mathrm{~g}, \mathrm{~h}}$ & $\begin{array}{l}\mathrm{C}_{\text {endo }} / \\
\mathrm{C}_{\text {exo }}{ }^{\mathrm{i}} \\
\end{array}$ & $\begin{array}{l}\mathrm{C}_{\text {endol }} / \\
\mathrm{C}_{\text {exo }}{ }^{\mathrm{j}} \\
\end{array}$ \\
\hline $\mathbf{3 a}$ & 78.13 & 42.90 & -35.23 & 105.39 & 27.26 & 105.55 & 27.42 & -0.16 & 1.234 & $55 / 45$ \\
\hline $\mathbf{3 b}$ & 70.92 & 35.84 & -35.08 & 98.35 & 27.43 & 98.52 & 27.60 & -0.17 & 1.250 & $56 / 44$ \\
\hline $3 \mathbf{c}$ & 72.49 & 36.96 & -35.53 & 98.95 & 28.03 & 99.12 & 26.63 & 1.40 & 0.159 & $14 / 86$ \\
\hline 3d & 65.81 & 30.30 & -35.51 & 92.51 & 26.70 & 92.64 & 26.83 & -0.13 & 1.186 & $54 / 46$ \\
\hline $3 e$ & 85.14 & 48.40 & -36.74 & 109.58 & 24.44 & 109.71 & 24.57 & -0.13 & 1.186 & $54 / 46$ \\
\hline \multirow[t]{2}{*}{ (b) } & \multicolumn{5}{|c|}{ Endo approach } & \multicolumn{5}{|c|}{ Exo approach } \\
\hline & $\Sigma \Delta H_{\mathrm{f}(\mathrm{r})}^{\mathrm{c}}$ & $\Delta H_{\mathrm{f}(\mathrm{p})}$ & $\Delta H^{o \mathrm{~d}}$ & $E_{\mathrm{TS}}{ }^{\mathrm{e}}$ & $\Delta H_{\text {(endo }}^{\#}{ }^{\mathrm{f}}$ & $E_{\mathrm{TS}}$ & $\Delta H_{(\text {exo })}^{\#}$ & $\begin{array}{r}\Delta \Delta H^{\#} \\
\mathrm{~g}, \mathrm{~h}\end{array}$ & $\begin{array}{l}\mathrm{C}_{\text {endo }} / \\
\mathrm{C}_{\text {exo }} \mathrm{i} \\
\end{array}$ & $\begin{array}{l}\mathrm{C}_{\text {endo }} / \\
\mathrm{C}_{\text {exo }} \mathrm{j}\end{array}$ \\
\hline 3a & 78.13 & 40.49 & -37.64 & 108.41 & 30.28 & 108.33 & 30.20 & 0.08 & 0.900 & $47 / 53$ \\
\hline $3 \mathbf{b}$ & 70.92 & 33.45 & -37.47 & 101.36 & 30.44 & 101.23 & 30.31 & 0.13 & 0.843 & $46 / 54$ \\
\hline $3 \mathbf{c}$ & 72.49 & 34.53 & -37.96 & 102.28 & 29.79 & 102.39 & 29.90 & -0.11 & 1.156 & $54 / 46$ \\
\hline 3d & 65.81 & 27.85 & -37.96 & 95.72 & 29.91 & 95.77 & 29.96 & -0.05 & 1.068 & $52 / 48$ \\
\hline $3 e$ & 85.14 & 45.90 & -39.24 & 113.35 & 28.21 & 114.03 & 28.89 & -0.68 & 2.444 & $71 / 29$ \\
\hline
\end{tabular}

${ }^{\text {a }} \Delta H_{f}$ for the reactants $\left(\right.$ at $383{ }^{\circ} \mathrm{K}$, in $\left.\mathrm{kcal} / \mathrm{mol}\right): \mathbf{1 0}=128.67 ; \mathbf{3 a}=-50.54 ; \mathbf{3 b}=-57.75 ; \mathbf{3} \mathbf{c}=-$ $56.18 ; \mathbf{3 d}=-62.86 ; \mathbf{3} \mathbf{e}=-43.53 ; \mathbf{4 a}=-19.06 ; \mathbf{4} \mathbf{b}=-13.14{ }^{\mathrm{b}} \quad$ The symbols have the same meaning as in Table 4.

Table 6. Calculated product ratio $7 / 8$ and $\mathbf{1 2} / \mathbf{1 3}$ according to their lower calculated activation parameters for endo or exo approach (in gas phase, $383{ }^{\circ} \mathrm{K}$, AM1)

\begin{tabular}{lrrrl|lrrrr}
\hline Reaction & $E_{(7) \mathrm{TS}}{ }^{\mathrm{a}}$ & $E_{(8) \mathrm{TS}}$ & $\Delta E_{\mathrm{TS}}$ & $\mathbf{7 / 8}$ & Reaction & $E_{(12) \mathrm{TS}}$ & $E_{(14) \mathrm{TS}}$ & $\Delta E_{\mathrm{TS}}$ & $\mathbf{1 2} / \mathbf{1 3}$ \\
\hline $\mathbf{3 a}+\mathbf{2}$ & 63.99 & 66.68 & -2.69 & $97 / 3$ & $\mathbf{3 a}+\mathbf{1 0}$ & 105.39 & 108.33 & -2.94 & $98 / 2$ \\
$\mathbf{3 b}+\mathbf{2}$ & 56.98 & 59.61 & -2.63 & $97 / 3$ & $\mathbf{3 b}+\mathbf{1 0}$ & 98.35 & 101.23 & -2.88 & $98 / 2$ \\
$\mathbf{3 c}+\mathbf{2}$ & 57.42 & 60.63 & -3.21 & $98 / 2$ & $\mathbf{3 c}+\mathbf{1 0}$ & 98.95 & 102.28 & -3.33 & $99 / 1$ \\
$\mathbf{3 d}+\mathbf{2}$ & 51.09 & 54.05 & -2.96 & $98 / 2$ & $\mathbf{3 d}+\mathbf{1 0}$ & 92.51 & 95.72 & -3.21 & $99 / 1$ \\
$\mathbf{3 e}+\mathbf{2}$ & 67.69 & 71.59 & -3.90 & $99 / 1$ & $\mathbf{3 e}+\mathbf{1 0}$ & 109.58 & 113.75 & -4.17 & $99 / 1$ \\
$\mathbf{4 a}+\mathbf{2}$ & 95.13 & 96.63 & -1.50 & $88 / 12$ & & & & & \\
$\mathbf{4 b}+\mathbf{2}$ & 99.93 & 101.62 & -1.69 & $90 / 10$ & & & & & \\
\hline
\end{tabular}

${ }^{\mathrm{a}} E_{\mathrm{TS}}$ is the lower transition state energy of the activated complex leading after deformylation to compound $7,8,12$ or 13 , correspondingly. 
The smaller reactivity of chromones $\mathbf{4}$ can be attributed mainly to the higher activation energy required to reach the TS. The computed activation energies $E_{\mathrm{TS}}{ }^{\#}$ of reactions between $\mathbf{2}+\mathbf{4 a}$ and $\mathbf{2}+\mathbf{4 b}$ for endo approach are $\sim 33 \mathrm{kcal} / \mathrm{mol}$ higher than the corresponding ones for $\mathbf{2}+\mathbf{3 a}$ and $2+3 \mathbf{e}$. To overcome this additional energy the temperature of the reaction must be increased. However, as mentioned earlier, by using boiling xylene as solvent only resinous material was formed.

\section{Conclusions}

In conclusion, an efficient route for the synthesis of new classes of fused tetrahydrochromeno carbazoles and indazoles has been described by incorporating the chromone moiety into the indole and pyrazole nuclei, respectively. The new products are formed by the combination of two extremely active biological components and such polycyclic molecules are known to display substantial biological activities. ${ }^{20}$ In all cases in situ deformylation of chromenone Diels-Alder adducts was observed. Frontier Molecular Orbital theory (FMO) predicted the reaction in all cases to be $\mathrm{HOMO}_{(\mathrm{qdm})}-\mathrm{LUMO}_{\text {(chromone) }}$ controlled. The observed regioselectivity is a result of the $\Delta \mathrm{c}$ difererence in absolute values of the $\mathrm{p}_{\mathrm{z}}$ orbital coefficients of the terminal reacting atoms in HOMO and LUMO and of the activation parameters calculated after locating the several TS involved. In addition, the theoretical prediction for the product ratio is in excellent agreement with the experimental results.

\section{Experimental Section}

General Procedures. Melting points were measured on a Kofler hot-stage and are uncorrected. Column chromatography was carried out using Merck silica gel. TLC was performed using precoated silica gel glass plates of $0.25 \mathrm{~mm}$ containing fluorescent indicator UV254 purchased from Macherey-Nagel using a 3:1 mixture of petroleum ether-ethyl acetate. Petroleum ether refers to the fraction boiling between 60 and $80^{\circ} \mathrm{C}$. NMR spectra were recorded on a Bruker AM 300 spectrometer at $300 \mathrm{MHz}$ for ${ }^{1} \mathrm{H}$ and $75 \mathrm{MHz}$ for ${ }^{13} \mathrm{C}$, respectively, using $\mathrm{CDCl}_{3}$ as solvent. Coupling constants ${ }^{n} J$ are reported in $\mathrm{Hz}$ and chemical shifts are expressed in $\delta$ values (ppm) relative to TMS as internal standard for ${ }^{1} \mathrm{H}$ and relative to TMS $(0.00 \mathrm{ppm})$ or to $\mathrm{CDCl}_{3}(77.05$ ppm) for ${ }^{13} \mathrm{C}$ NMR spectra. Second order ${ }^{1} \mathrm{H}$ NMR spectra were analysed by simulation. ${ }^{17}$ IR spectra were recorded on a Perkin-Elmer 1600 series FTIR spectrometer and are reported in wave numbers $\left(\mathrm{cm}^{-1}\right)$. Low-resolution electron impact mass spectra (EIMS) were obtained either on a VG TS-250 instrument or on a 6890N GC/MS system (Agilent Technology) and elemental analyses performed with a Perkin-Elmer 2400-II CHN analyzer. The MO calculations for minimum energy conformation of compounds were computed with the AM1 method as implemented in the MOPAC package. ${ }^{21}$ All stationary points were refined by minimization of 
the gradient norm of the energy to at least $0.005 \mathrm{kcal} / \mathrm{mol}$. Structural assignments of the derived compounds were established by analysis of their elemental analyses, IR, MS, and NMR spectra $\left({ }^{1} \mathrm{H},{ }^{13} \mathrm{C}, \mathrm{COSY}\right.$, NOESY, HETCOR, and COLOC).

General procedure for the Diels-Alder reactions of 3-formylchromones (3a-3e) with indole o-quinodimethane 2

To a stirred solution of $\mathbf{3}(5.0 \mathrm{mmol})$ in dry toluene $(25 \mathrm{~mL}), 18$-crown-6 ether was added $(0.581$ $\mathrm{g}, 2.2 \mathrm{mmol})$ followed by the addition of 1-benzoyl-2,3-bisbromomethylindole (1) (0.407 $\mathrm{g}, 1.0$ $\mathrm{mmol})$ and finally sodium iodide $(0.33 \mathrm{~g}, 2.2 \mathrm{mmol})$. The reaction mixture was stirred at reflux under nitrogen for $10 \mathrm{~h}$. The solvent was distilled off and the resulting residue was subjected to the following procedure in order to remove the excess of chromone, except in the case of nitro derivative. The residue was dissolved in $10 \mathrm{~mL}$ of dichoromethane and washed initially with $2 \times 10 \mathrm{~mL}$ of $5 \%$ sodium hydroxide, then with $5 \%$ ammonium chloride and finally with water. The organic phase was dried with anhydrous sodium sulphate, the solvent was distilled off and the residue was subjected to column chromatography on silica gel using petroleum ether/EtOAc (7:1) as eluent, to give in order of elution an inseparable mixture of $\mathbf{5}$ and $\mathbf{6}$ and a second inseparable mixture of $\mathbf{7}$ and $\mathbf{8}$.

\section{From compound 3a}

(5aR,12a $R$ or 5aS,12aS)-7-Benzoyl-6,7,12,12a-tetrahydrochromeno[2,3-b]carbazol-13(5aH)one (5a) and $(5 \mathrm{a} R, 12 \mathrm{a} R$ or $5 \mathrm{a} S, 12 \mathrm{a} S)-11-B e n z o y l-6,11,12,12 \mathrm{a}-$ tetrahydrochromeno[3,2b]carbazol-13(5aH)-one (6a) in a 10:1 ratio. Overal yield $0.122 \mathrm{~g}, 31 \%$. From this mixture a pure sample of the major isomer $5 \mathbf{a}$ was obtained after recrystallization from $\mathrm{CH}_{2} \mathrm{Cl}_{2}-\mathrm{Et}_{2} \mathrm{O}$ as a white solid, $\operatorname{mp} 235-237{ }^{\circ} \mathrm{C}$; IR (KBr) $v_{\max }$ : $1682,1606 \mathrm{~cm}^{-1} .{ }^{1} \mathrm{H}$ NMR $\delta 2.824$ (dddd, $J=17.2$, $\left.10.8,3.3,1.7 \mathrm{~Hz}, 1 \mathrm{H}, 12-\mathrm{H}_{\mathrm{ax}}\right){ }^{17} 3.102$ (ddd, $J=13.3,10.8,6.1 \mathrm{~Hz}, 1 \mathrm{H}, 12 \mathrm{a}-\mathrm{H}_{\mathrm{ax}}$ ), 3.306 (dddd, $J$ $\left.=17.0,9.6,3.3,1.7 \mathrm{~Hz}, 1 \mathrm{H}, 6-\mathrm{H}_{\mathrm{ax}}\right), 3.460$ (dddd, $J=17.0,6.1,1.7,0.5 \mathrm{~Hz}, 1 \mathrm{H}, 6-\mathrm{H}_{\mathrm{eq}}$ ), 3.499 (dddd, $J=17.2,6.1,1.7,0.5 \mathrm{~Hz}, 1 \mathrm{H}, 12-\mathrm{H}_{\mathrm{eq}}$ ), $4.622\left(\mathrm{ddd}, J=13.3,9.6,6.1 \mathrm{~Hz}, 1 \mathrm{H}, 5 \mathrm{a}-\mathrm{H}_{\mathrm{ax}}\right.$ ), 6.99 $(\mathrm{dd}, J=8.3,1.1 \mathrm{~Hz}, 1 \mathrm{H}, 8-\mathrm{H}),{ }^{17} 7.02(\mathrm{ddd}, J=8.0,1.1,0.4 \mathrm{~Hz}, 1 \mathrm{H}, 4-\mathrm{H}), 7.06$ (ddd, $J=7.9,7.2$, $1.1 \mathrm{~Hz}, 1 \mathrm{H}, 2-\mathrm{H}), 7.08$ (ddd, $J=8.3,7.1,1.3 \mathrm{~Hz}, 1 \mathrm{H}, 9-\mathrm{H}), 7.222(\mathrm{ddd}, J=8.2,7.1,1.1 \mathrm{~Hz}, 1 \mathrm{H}$, 10-H), 7.48-7.52 (m, 2H, 3,11-H), 7.52-7.56 (m, 2H, 3',5'-H), 7.667 (tt, J=7.45, $1.6 \mathrm{~Hz}, 1 \mathrm{H}, 4^{\prime}-$ $\mathrm{H}), 7.72-7.76\left(\mathrm{~m}, 2 \mathrm{H}, 2^{\prime}, 6{ }^{\prime}-\mathrm{H}\right), 7.965$ (ddd, $\left.J=7.9,1.8,0.4 \mathrm{~Hz}, 1 \mathrm{H}, 1-\mathrm{H}\right) .{ }^{13} \mathrm{C} \mathrm{NMR}(75 \mathrm{MHz}$, $\left.\mathrm{CDCl}_{3}\right) \delta 19.82(\mathrm{C}-12), 32.07$ (C-6), 45.67 (C-12a), 77.72 (C-5a), $114.72(\mathrm{C}-8), 115.87(\mathrm{C}-11 \mathrm{~b})$, 117.91 (C-4), 118.37 (C-11), 120.72 (C-13a), 121.69 (C-2), 123.05 (C-10), 123.78 (C-9), 127.25 (C-1), 128.88 (C-3',5'), 128.94 (C-11a), 129.48 (C-2',6'), 131.55 (C-6a), 132.83 (C-4'), 135.42 (C-1'), 136.24 (C-3), 137.06 (C-7a), 161.27 (C-4a), 169.00 (NCO), 193.49 (C-13). EIMS m/z (\%) 393 (4, M ${ }^{+}$), 392 (57), 373 (8), 288 (40), 269 (45), 166 (95), 143 (27), 130 (35), 105 (45), 104 (62), 77 (100). Anal. calcd for $\mathrm{C}_{26} \mathrm{H}_{19} \mathrm{NO}_{3}$ (393.43): C, 79.37; H, 4.87; N, 3.56. Found: C, 79.25; H, 4.92; N. 3.50\%.

After isolation of 5a some NMR data ${ }^{21}$ of the minor isomer 6 a were also deduced: ${ }^{1} \mathrm{H}$ NMR $\delta$ $4.714(\mathrm{ddd}, J=13.4,9.6,6.3 \mathrm{~Hz}, 1 \mathrm{H}, 5 \mathrm{a}-\mathrm{H}), 7.915(\mathrm{dd}, J=8.0,1.7 \mathrm{~Hz}, 1 \mathrm{H}, 1-\mathrm{H}) .{ }^{13} \mathrm{C} \mathrm{NMR}(75$ 
$\left.\mathrm{MHz}, \mathrm{CDCl}_{3}\right) \delta 24.24$ (C-12), 28.08 (C-6), 46.55 (C-12a), 77.33 (C-5a), 114.83 (C-10), 115.82 (C-6a), 118.00 (C-4), 118.52 (C-7), 120.32 (C-13a), 121.34 (C-2), 122.43 (C-8), 123.54 (C-9), 127.33 (C-1), 128.80 (C-3',5'), 129.31 (C-11a), 129.40 (C-2',6'), 130.80 (C-6a), 133.38 (C-4'), 135.35 (C-1'), 136.04 (C-3), 136.95 (C-10a).

$(5 \mathrm{a} R, 12 \mathrm{a} S$ or $5 \mathrm{a} S, 12 \mathrm{a} R)-7-B e n z o y l-6,7,12,12 \mathrm{a}-$ tetrahydrochromeno[2,3-b]carbazol-13(5aH)one (7a) and $(5 \mathrm{a} S, 12 \mathrm{a} R$ or $5 \mathrm{a} R, 12 \mathrm{a} S)-11-b e n z o y l-6,11,12,12 \mathrm{a}-$ tetrahydrochromeno[3,2b]carbazol-13(5aH)-one (8a) in a 2:1 ratio. $0.102 \mathrm{~g}, 26 \%$ Yield, white solid, mp $254-258{ }^{\circ} \mathrm{C}$ $\left(\mathrm{CH}_{2} \mathrm{Cl}_{2}\right.$-pet. ether); IR (KBr) $v_{\max }$ : 1687, 1606, 1457, $1300 \mathrm{~cm}^{-1}$. EIMS m/z (\%) $393\left(60, \mathrm{M}^{+}\right)$, 374 (8), 288 (10), 270 (15), 246 (8), 167 (15), 105 (100), 77 (35). Anal. calcd for $\mathrm{C}_{26} \mathrm{H}_{19} \mathrm{NO}_{3}$ (393.43): C, 79.37; H, 4.87; N, 3.56. Found: C, 79.52; H, 4.72; N. 3.67\%.

Major isomer 7a. ${ }^{1} \mathrm{H}$ NMR $\delta 2.98-3.03(\mathrm{~m}, 2 \mathrm{H}, 12-\mathrm{H}), 3.04-3.09(\mathrm{~m}, 1 \mathrm{H}, 12 \mathrm{a}-\mathrm{H}), 3.33-3.38$ $(\mathrm{m}, 2 \mathrm{H}, 6-\mathrm{H}), 5.00-5.05(\mathrm{~m}, 1 \mathrm{H}, 5 \mathrm{a}-\mathrm{H}), 6.87(\mathrm{dd}, J=8.4,1.0 \mathrm{~Hz}, 1 \mathrm{H}, 8-\mathrm{H}), 6.96$ (dd, $J=8.4,1.0$ $\mathrm{Hz}, 1 \mathrm{H}, 4-\mathrm{H}), 7.00-7.08$ (m, 2H, 2,9-H), 7.17 (ddd, $J=7.9,7.2,1.0 \mathrm{~Hz}, 1 \mathrm{H}, 10-\mathrm{H}), 7.48$ (ddd, $J$ $=8.4,7.1,1.8 \mathrm{~Hz}, 1 \mathrm{H}, 3-\mathrm{H}), 7.49-7.55\left(\mathrm{~m}, 3 \mathrm{H}, 11,3^{\prime}, 5^{\prime}-\mathrm{H}\right), 7.646$ (tt, $\left.J=7.5,1.4 \mathrm{~Hz}, 1 \mathrm{H}, 4^{\prime}-\mathrm{H}\right)$, 7.71-7.76 (m, 2H, 2',6'-H), $7.951(\mathrm{dd}, J=7.9,1.8 \mathrm{~Hz}, 1 \mathrm{H}, 1-\mathrm{H}) .{ }^{13} \mathrm{C}$ NMR $\left(75 \mathrm{MHz}, \mathrm{CDCl}_{3}\right) \delta$ 19.27 (C-12), 30.00 (C-6), 44.26 (C-12a), 75.10 (C-5a), 114.70 (C-8), 115.90 (C-11b), 117.91 (C-13a), 118.00, 118.10 (C-4, C-11), 121.72 (C-2), 122.90 (C-10), 123.55 (C-9), 127.58 (C-1), 128.78 (C-3',5'), 129.14 (C-11a), 129.45 (C-2',6'), 131.89 (C-6a), 132.73 (C-4'), 135.41 (C-1'), 136.17 (C-3), 136.58 (C-7a), 160.86 (C-4a), 169.15 (7-CO), 194.62 (C-13).

Some NMR data for the minor isomer 8a were also deduced: ${ }^{1} \mathrm{H}$ NMR $\delta$ 5.07-5.12 (m, 1H, 5aH), 7.18 (ddd, $J=7.9,7.2,1.0 \mathrm{~Hz}, 1 \mathrm{H}, 8-\mathrm{H}), 7.68-7.72\left(\mathrm{~m}, 2 \mathrm{H}, 2^{\prime}, 66^{\prime}-\mathrm{H}\right), 7.897$ (dd, $J=7.9,1.8$ $\mathrm{Hz}, 1 \mathrm{H}, 1-\mathrm{H}) ;{ }^{13} \mathrm{C}$ NMR $\left(75 \mathrm{MHz}, \mathrm{CDCl}_{3}\right) \delta 22.70$ (C-12), 25.64 (C-6), 45.38 (C-12a), 74.93 (C5a), 114.72 (C-10), 115.85 (C-6a), 118.03 (C-7), 119.33 (C-4), 119.60 (C-13a), 121.60 (C-2), 122.78 (C-8), 123.59 (C-9), 127.59 (C-1), 128.88 (C-3',5'), 129.16 (C-6b), 129.45 (C-2',6'), 131.52 (C-11a), 132.85 (C-4'), 135.31 (C-1'), 136.17 (C-3), 136.74 (C-10a), 160.64 (C-4a), 169.06 (7-CO), 193.67 (C-13).

\section{From compound 3b}

(5aR,12aS or 5aS,12aR)-7-Benzoyl-2-methyl-6,7,12,12a-tetrahydrochromeno[2,3-b]carbazol-13(5aH)-one (7b) and $(5 \mathrm{a} S, 12 \mathrm{a} R$ or $5 \mathrm{a} R, 12 \mathrm{a} S)-11-b e n z o y l-2-m e t h y l-6,11,12,12 \mathrm{a}-$ tetrahydrochromeno[3,2-b]carbazol-13(5aH)-one $(\mathbf{8 b})$ in a $2: 1$ ratio. $0.179 \mathrm{~g}, 44 \%$ Yield, white solid, mp $154-158{ }^{\circ} \mathrm{C}\left(\mathrm{CH}_{2} \mathrm{Cl}_{2}\right.$-pet. ether); IR (KBr) $v_{\max }: 1684,1644 \mathrm{~cm}^{-1}$. The ${ }^{1} \mathrm{H}$ NMR of the mixture consists of overlapping multiplets. Only the protons $\mathrm{H}_{5 \mathrm{a}}$ of both compounds are well discriminated, giving multiplets at 4.97-5.01 and 5.04-5.10 ppm, and allowing the measurement of the mixture composition.

Major isomer 7b. ${ }^{1} \mathrm{H}$ NMR $\delta 2.326\left(\mathrm{~s}, 3 \mathrm{H}, 2-\mathrm{CH}_{3}\right), 2.94-3.30(\mathrm{~m}, 3 \mathrm{H}, 12-\mathrm{H}, 12 \mathrm{a}-\mathrm{H}), 3.32-3.37$ (m, 2H, 6-H), 4.97-5.01 (m, 1H, 5a-H), 6.857 (d, $J=8.5 \mathrm{~Hz}, 1 \mathrm{H}, 4-\mathrm{H}), 6.881$ (dd, $J=8.3,1.1$ $\mathrm{Hz}, 1 \mathrm{H}, 8-\mathrm{H}$ ), 7.031 (ddd, $J=8.4,7.3,1.3 \mathrm{~Hz}, 1 \mathrm{H}, 9-\mathrm{H}), 7.167$ (ddd, $J=7.7,7.3,1.0 \mathrm{~Hz}, 1 \mathrm{H}, 10-$ H), $7.388(\mathrm{dd}, J=8.5,1.3 \mathrm{~Hz}, 1 \mathrm{H}, 3-\mathrm{H}), 7.40-7.44$ (m, 1H, 11-H), 7.50-7.55 (m, 2H, 3',5'-H), 7.61-7.69 (m, 1H, 4'-H ), 7.67-7.73 (m, 2H, 2',6'-H), 7.750 (d, J=1.3 Hz, 1H, 1-H). ${ }^{13} \mathrm{C}$ NMR 
$\left(75 \mathrm{MHz}, \mathrm{CDCl}_{3}\right) \delta 19.36(\mathrm{C}-12), 20.48\left(2-\mathrm{CH}_{3}\right), 30.09(\mathrm{C}-6), 44.28(\mathrm{C}-12 \mathrm{a}), 75.32$ (C-5a), 114.70 (C-8), 115.99 (C-11b), 117.77 (C-4), 118.10 (C-11), 118.87 (C-13a), 122.91 (C-10), 123.55 (C-9), 127.15 (C-1), 128.84 (C-3',5'), 129.18 (C-11a), 129.47 (C-2',6'), 131.22 (C-2), 131.98 (C-6a), 132.75 (C-4'), 135.42 (C-1'), 136.73 (C-7a), 137.31 (C-3), 158.94 (C-4a), 169.18 (7-CO), 195.02 (C-13). EIMS m/z (\%) 407 (1, M ${ }^{+}$), 389 (2), 284 (10), 268 (7), 254 (5), 217 (15), 167 (8), 143 (8), 127 (10), 115 (10), 105 (55), 77 (100). Anal. calcd for $\mathrm{C}_{27} \mathrm{H}_{21} \mathrm{NO}_{3}$ (407.46): C, 79.59; H, 5.19; N, 3.44. Found: C, 79.72; H, 4.99; N. 3.57\%.

Some NMR data for the minor isomer 8b were also deduced: ${ }^{1} \mathrm{H}$ NMR $\delta 2.315\left(\mathrm{~s}, 3 \mathrm{H}, 2-\mathrm{CH}_{3}\right)$, 5.04-5.10 (m, 1H, 5a-H), 6.892 (d, $J=8.6 \mathrm{~Hz}, 1 \mathrm{H}, 4-\mathrm{H}), 7.031$ (ddd, $J=8.4,7.3,1.3 \mathrm{~Hz}, 1 \mathrm{H}, 9$ $\mathrm{H}), 7.185$ (ddd, $J=7.7,7.3,1.0 \mathrm{~Hz}, 1 \mathrm{H}, 10-\mathrm{H}) .{ }^{13} \mathrm{C} \mathrm{NMR}\left(75 \mathrm{MHz}, \mathrm{CDCl}_{3}\right) \delta 22.78(\mathrm{C}-12)$, $25.45\left(2-\mathrm{CH}_{3}\right), 29.74(\mathrm{C}-6), 45.33$ (C-12a), 74.84 (C-5a), 114.50 (C-10), 116.13 (C-6a), 117.63 (C-4), 117.91 (C-7), 118.32 (C-13a), 122.79 (C-8), 123.58 (C-9), 127.08 (C-1), 128.81 (C-3',5'), 129.24 (C-6b), 129.47 (C-2',6'), 131.12 (C-2), 132.48 (C-11a), 132.78 (C-4'), 135.32 (C-1'), 136.35 (C-10a), 137.31 (C-3), 158.73 (C-4a), 168.96 (11-CO), 194.04 (C-13).

\section{From compound $3 \mathrm{c}$}

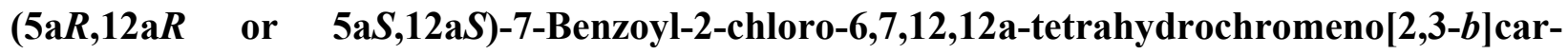
bazol-13(5aH)-one (5c) and $(5 \mathrm{aR}, 12 \mathrm{a} R$ or $5 \mathrm{aS}, 12 \mathrm{aS})-11-b e n z o y l-2-c h l o r o-6,11,12,12 \mathrm{a}-$ tetrahydrochromeno[3,2-b]carbazol-13(5aH)-one (6c) in a 3.5:1 ratio. $0.124 \mathrm{~g}, 29 \%$ Yield. White solid $\left(\mathrm{CH}_{2} \mathrm{Cl}_{2}-\mathrm{Et}_{2} \mathrm{O}\right)$, mp 270-274 ${ }^{\circ} \mathrm{C}$; IR (KBr) v $\max : 1690,1679,1602,1471,1353 \mathrm{~cm}^{-1}$. EIMS m/z (\%) 427/429 (4, M+*), 323/325 (10), 304/306 (18), 168 (23), 167 (66), 166 (33), 164 (11), 139 (22), 130 (15), 115 (12), 105 (75), 77 (100). Anal. calcd for $\mathrm{C}_{26} \mathrm{H}_{18} \mathrm{ClNO}_{3}$ (427.88): C, 72.78; H, 4.24; N, 3.27. Found: C, 72.69; H, 4.42; N. 3.23\%.

Major isomer 5c. ${ }^{1} \mathrm{H}$ NMR $\delta 2.819$ (dddd, $J=17.2,10.8,3.2,1.7 \mathrm{~Hz}, 1 \mathrm{H}, 12-\mathrm{H}_{\mathrm{ax}}$ ), 3.098 (ddd, $J$ $\left.=13.4,10.8,6.1 \mathrm{~Hz}, 1 \mathrm{H}, 12 \mathrm{a}-\mathrm{H}_{\mathrm{ax}}\right), 3.326$ (dddd, $\left.J=17.0,9.5,3.2,1.7 \mathrm{~Hz}, 1 \mathrm{H}, 6-\mathrm{H}_{\mathrm{ax}}\right), 3.45-3.55$ $\left(\mathrm{m}, 2 \mathrm{H}, 6-\mathrm{H}_{\mathrm{eq}}, 12-\mathrm{H}_{\mathrm{eq}}\right), 4.623\left(\mathrm{ddd}, J=13.4,9.6,6.2 \mathrm{~Hz}, 1 \mathrm{H}, 5 \mathrm{a}-\mathrm{H}_{\mathrm{ax}}\right), 6.962$ (ddd, $J=8.3,1.2$, $0.5 \mathrm{~Hz}, 1 \mathrm{H}, 8-\mathrm{H}), 6.980$ (d, $J=8.9 \mathrm{~Hz} .1 \mathrm{H}, 4-\mathrm{H}), 7.085$ (ddd, $J=8.3,7.3,1.2 \mathrm{~Hz}, 1 \mathrm{H}, 9-\mathrm{H}$ ), $7.226(\mathrm{ddd}, J=8.3,7.3,1.0 \mathrm{~Hz}, 1 \mathrm{H}, 10-\mathrm{H}), 7.448(\mathrm{dd}, J=9.0,2.6 \mathrm{~Hz}, 1 \mathrm{H}, 3-\mathrm{H}), 7.505(\mathrm{dd}, J=$ 7.4, 1.1 Hz, 1H, 11-H), 7.49-7.57 (m, 2H, 3',5'-H), 7.64-7.70 (m, 1H, 4'-H), 7.72-7.76 (m, 2H, $\left.2^{\prime}, 6^{\prime}-\mathrm{H}\right), 7.915$ (d, $\left.J=2.6 \mathrm{~Hz}, 1 \mathrm{H}, 1-\mathrm{H}\right) .{ }^{13} \mathrm{C} \mathrm{NMR}\left(75 \mathrm{MHz}, \mathrm{CDCl}_{3}\right) \delta 19.79(\mathrm{C}-12), 31.95(\mathrm{C}-6)$, 45.49 (C-12a), 77.98 (C-5a), 114.74 (C-8), 115.70 (C-11b), 118.01 (C-13a), 118.39 (C-11), 119.69 (C-4), 123.11 (C-10), 123.86 (C-9), 126.56 (C-1), 127.28 (C-2), 128.84 (C-11a), 128.92 (C-3',5'), 129.51 (C-2',6'), 131.39 (C-6a), 132.92 (C-4'), 135.31 (C-1'), 136.02 (C-3), 137.01 (C7a), 159.71 (C-4a), 169.03 (7-CO), 192.50 (C-13).

Some NMR data of the minor isomer 6c were also deduced: ${ }^{1} \mathrm{H}$ NMR $\delta 4.706$ (ddd, $J=13.3$, 9.6, 6.1 Hz, 1H, H-5a), 7.100 (ddd, $J=8.3,7.3,1.2 \mathrm{~Hz}, 1 \mathrm{H}, 9-\mathrm{H}), 7.867$ (d, $J=2.6 \mathrm{~Hz}, 1 \mathrm{H}, 1-\mathrm{H})$.

${ }^{13} \mathrm{C}$ NMR $\left(75 \mathrm{MHz}, \mathrm{CDCl}_{3}\right) \delta 24.16(\mathrm{C}-12), 27.97$ (C-6), 46.38 (C-12a), 77.47 (C-5a), 114.82 (C-10), 118.00 (C-7), 119.59 (C-4), 122.94 (C-8), 126.63 (C-1), 128.92 (C-3',5'), 129.51 (C2',6'), 128.78 (C-11a), 132.96 (C-4'), 135.96 (C-3), 159.60 (C-4a), 169.00 (7-CO), 192.50 (C-13).

$(5 \mathrm{a} R, 12 \mathrm{a} S$ or $5 \mathrm{aS}, 12 \mathrm{a} R)-7-B e n z o y l-2-c h l o r o-6,7,12,12 \mathrm{a}-t e t r a h y d r o c h r o m e n o[2,3-b]$ carbazol-13(5aH)-one (7c) and $(5 \mathrm{a} S, 12 \mathrm{a} R$ or $5 \mathrm{a} R, 12 \mathrm{a} S)-11-b e n z o y l-2-c h l o r 0-6,11,12,12 \mathrm{a}-$ 
tetrahydrochromeno $[3,2-b]$ carbazol-13(5aH)-one $(8 c)$ in a $4: 1$ ratio. $0.145 \mathrm{~g}, 34 \%$ Yield, white solid, mp 200-204 ${ }^{\circ} \mathrm{C}\left(\mathrm{CH}_{2} \mathrm{Cl}_{2}\right.$-pet. ether); IR (KBr) $v_{\text {max }}: 1688,1603 \mathrm{~cm}^{-1}$. EIMS m/z (\%) 427/429 (10, $\mathrm{M}^{+}$), $411 / 413$ (10), 322 (5), 304 (3), 271 (3), 263 (10), 246 (5), 220 (10), 209 (8), 167 (8), 105 (100), 77 (80). Anal. calcd for $\mathrm{C}_{26} \mathrm{H}_{18} \mathrm{ClNO}_{3}$ (427.88): C, 72.98; H, 4.24; N, 3.27. Found: C, 73.09; H, 4.35; N. 3.15\%.

Major isomer 7c. ${ }^{1} \mathrm{H}$ NMR $\delta$ 2.94-3.02 (m, 2H, 12-H), 3.05-3.12 (m, 1H, 12a-H), 3.34-3.39 (m, 2H, 6-H), 5.014 (ddd, $\left.J=4.1,4.0,2.4 \mathrm{~Hz}, 1 \mathrm{H}, 5 \mathrm{a}-\mathrm{H}_{\mathrm{eq}}\right), 6.850$ (ddd, $J=8.3,1.2,0.6 \mathrm{~Hz}, 1 \mathrm{H}$, 8-H), 6.917 (d, $J=8.9 \mathrm{~Hz}, 1 \mathrm{H}, 4-\mathrm{H}), 7.031$ (ddd, $J=8.3,7.2,1.0 \mathrm{~Hz}, 1 \mathrm{H}, 9-\mathrm{H}), 7.170$ (ddd, $J=$ 7.8, 7.2, $1.2 \mathrm{~Hz}, 1 \mathrm{H}, 10-\mathrm{H}), 7.387$ (ddd, $J=7.8,1.0,0.6 \mathrm{~Hz}, 1 \mathrm{H}, 11-\mathrm{H}), 7.415$ (dd, $J=8.9,2.7$ Hz, 1H, 3-H), 7.48-7.55 (m, 2H, 3',5'-H), 7.648 (tt, $\left.J=7.5,2.0 \mathrm{~Hz}, 1 \mathrm{H}, 4{ }^{\prime}-\mathrm{H}\right), 7.71-7.75$ (m, 2H, 2',6'-H), 7.900 (d, $J=2.7 \mathrm{~Hz}, 1 \mathrm{H}, 1-\mathrm{H}) .{ }^{13} \mathrm{C} \mathrm{NMR}\left(75 \mathrm{MHz}, \mathrm{CDCl}_{3}\right) \delta 19.19(\mathrm{C}-12), 29.83(\mathrm{C}-6)$, 44.02 (C-12a), 75.70 (C-5a), 114.69 (C-8), 115.68 (C-11b), 117.91 (C-13a), 118.13 (C-11), 119.75 (C-4), 122.97 (C-10), 123.67 (C-9), 126.92 (C-1), 127.29 (C-2), 128.87 (C-3',5'), 129.06 (C-11a), 129.47 (C-2',6'), 131.73 (C-6a), 132.80 (C-4'), 135.38 (C-1'), 136.01 (C-3), 136.61 (C7a), 159.30 (C-4a), 169.13 (7-CO), 193.38 (C-13).

Some NMR data for the minor isomer 8c were also deduced: ${ }^{1} \mathrm{H}$ NMR $\delta 3.13-3.23(\mathrm{~m}, 1 \mathrm{H}, 12 \mathrm{a}-$ H), 5.090 (ddd, $J=4.1,4.0,2.4 \mathrm{~Hz}, 1 \mathrm{H}, 5 \mathrm{a}-\mathrm{H}), 6.861$ (ddd, $J=8.3,1.2,0.6 \mathrm{~Hz}, 1 \mathrm{H}, 10-\mathrm{H}), 7.041$ (ddd, $J=8.3,7.2,1.2 \mathrm{~Hz}, 1 \mathrm{H}, 9-\mathrm{H}), 7.181$ (ddd, $J=7.8,7.2,1.2 \mathrm{~Hz}, 1 \mathrm{H}, 8-\mathrm{H}), 7.437$ (dd, $J=$ 8.8, $2.8 \mathrm{~Hz}, 1 \mathrm{H}, 3-\mathrm{H}), 7.848(\mathrm{~d}, J=2.8 \mathrm{~Hz}, 1 \mathrm{H}, 1-\mathrm{H}) .{ }^{13} \mathrm{C} \mathrm{NMR}\left(75 \mathrm{MHz}, \mathrm{CDCl}_{3}\right) \delta 22.61(\mathrm{C}-$ 12), 25.26 (C-6), 45.05 (C-12a), 75.24 (C-5a), 113.29 (C-6a), 114.83 (C-10), 118.14 (C-7), 118.38 (C-13a), 119.79 (C-4), 122.84 (C-8), 123.70 (C-9), 126.83 (C-1), 127.17 (C-2), 128.83 (C-3',5'), 128.95 (C-6b), 129.47 (C-2',6'), 131.37 (C-11a), 132.84 (C-4'), 135.28 (C-1'), 136.01 (C-3), 136.77 (C-10a), 159.10 (C-4a), 169.03 (7-CO), 192.50 (C-13).

\section{From compound 3d}

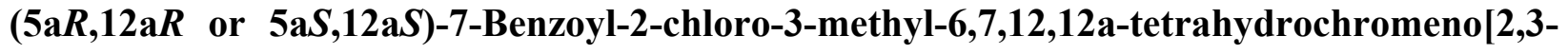

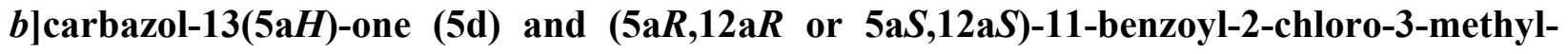
6,11,12,12a-tetrahydrochromeno[3,2-b]carbazol-13(5aH)-one (6d) in a 10:1 ratio. $0.102 \mathrm{~g}$, $23 \%$ Yield. White solid $\left(\mathrm{CH}_{2} \mathrm{Cl}_{2}-\mathrm{Et}_{2} \mathrm{O}\right), \mathrm{mp} 243-245^{\circ} \mathrm{C}$; IR $(\mathrm{KBr}) v_{\max }$ : 1686, 1611, 1457, 1357 $\mathrm{cm}^{-1}$. EIMS m/z (\%) 441/443 (4, M+), 390 (2), 337 (2), 318 (2), 247 (3), 207 (2), 167 (10), 140 (8), 127 (5), 105 (100), 77 (60). Anal. calcd for $\mathrm{C}_{27} \mathrm{H}_{20} \mathrm{ClNO}_{3}$ (441.91): C, 73.38; H, 4.56; N, 3.17. Found: C, 73.51; H, 4.62; N. 3.02\%.

Major isomer 5d. ${ }^{1} \mathrm{H}$ NMR $\delta 2.389\left(\mathrm{~s}, 3 \mathrm{H}, \mathrm{CH}_{3}\right), 2.796$ (dddd, $J=17.2,10.8,3.3,1.7 \mathrm{~Hz}, 1 \mathrm{H}$, $\left.12-\mathrm{H}_{\mathrm{ax}}\right), 3.058\left(\mathrm{ddd}, J=13.3,10.8,6.1 \mathrm{~Hz}, 1 \mathrm{H}, 12 \mathrm{a}-\mathrm{H}_{\mathrm{ax}}\right), 3.300$ (dddd, $J=17.0,9.6,3.3,1.7 \mathrm{~Hz}$, $1 \mathrm{H}, 6-\mathrm{H}_{\mathrm{ax}}$ ), 3.456 (ddd, $J=17.0,6.1,1.7 \mathrm{~Hz}, 1 \mathrm{H}, 6-\mathrm{H}_{\mathrm{eq}}$ ), 3.485 (ddd, $J=17.2,6.1,1.7 \mathrm{~Hz}, 1 \mathrm{H}$, $\left.12-\mathrm{H}_{\mathrm{eq}}\right), 4.584$ (ddd, $\left.J=13.3,9.6,6.1 \mathrm{~Hz}, 1 \mathrm{H}, 5 \mathrm{a}-\mathrm{H}_{\mathrm{ax}}\right), 6.908(\mathrm{~s}, 1 \mathrm{H}, 4-\mathrm{H}), 6.962$ (dd, $J=8.4,1.1$ $\mathrm{Hz}, 1 \mathrm{H}, 8-\mathrm{H}$ ), 7.075 (ddd, $J=8.4,7.1,1.1 \mathrm{~Hz}, 1 \mathrm{H}, 9-\mathrm{H}), 7.217$ (ddd, $J=8.1,7.1,1.1 \mathrm{~Hz}, 1 \mathrm{H}, 10-$ H), $7.498(\mathrm{dd}, J=8.1,1.1 \mathrm{~Hz}, 1 \mathrm{H}, 11-\mathrm{H}), 7.50-7.56\left(\mathrm{~m}, 2 \mathrm{H}, 3^{\prime}, 5^{\prime}-\mathrm{H}\right), 7.668$ (tt, $J=8.1,1.7 \mathrm{~Hz}$, 1H, 4'-H ), 7.71-7.76 (m, 2H, 2',6'-H), 7.897 (s, 1H, 1-H). ${ }^{13} \mathrm{C}$ NMR (75 MHz, CDCl 3 ) $\delta 19.80$ (C-12), 20.87 (3- $\left.\mathrm{CH}_{3}\right), 31.97$ (C-6), 45.42 (C-12a), 77.93 (C-5a), 114.72 (C-8), 115.79 (C-11b), 
117.98 (C-13a), 118.38 (C-11), 119.98 (C-4), 123.08 (C-10), 123.81 (C-9), 126.87 (C-1), 126.94 (C-2), 128.80 (C-11a), 128.90 (C-3',5'), 129.50 (C-2',6'), 131.45 (C-6a), 132.88 (C-4'), 135.32 (C-1'), 136.99 (C-7a), 145.27 (C-3), 159.53 (C-4a), 169.01 (7-CO), 192.32 (C-13).

Some NMR data of the minor isomer $6 \mathbf{d}$ were also deduced: ${ }^{1} \mathrm{H}$ NMR $\delta 2.40\left(\mathrm{~s}, 3 \mathrm{H}, \mathrm{CH}_{3}\right), 4.60$ 4.73 (m, 1H, H-5a), 6.94 (s, 1H, H-4), 7.85 (s, 1H, H-1). $\left.{ }^{13} \mathrm{C} \mathrm{NMR} \mathrm{(75} \mathrm{MHz,} \mathrm{CDCl}\right) \delta 22.64(\mathrm{C}-$ 12), $24.18\left(\mathrm{CH}_{3}-2\right), 31.60$ (C-6), 46.30 (C-12a), 114.80 (C-10), 115.83 (C-6a), 122.92 (C-8), 128.90 (C-3',5'), 129.50 (C-2',6'), 133.02 (C-11a), 133.41 (C-4'), 135.29 (C-1'), 137.05 (C-10a), 145.18 (C-3), 159.42 (C-4a), 169.05 (11-CO), 191.52 (C-13).

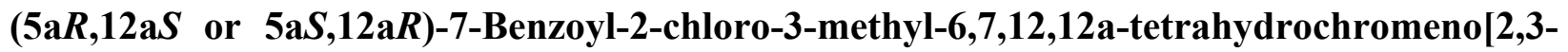
$b$ carbazol-13(5aH)-one (7d) and (5aS,12aR or 5aR,12aS)-11-benzoyl-2-chloro-3-methyl6,11,12,12a-tetrahydrochromeno[3,2-b]carbazol-13(5aH)-one $(\mathbf{8 d})$ in a 2.5:1 ratio. $0.141 \mathrm{~g}$, $32 \%$ Yield, white solid, mp $180-185^{\circ} \mathrm{C}\left(\mathrm{CH}_{2} \mathrm{Cl}_{2}\right.$-pet. ether); IR (KBr) $v_{\max }$ : 1693, 1655, 1609 , 1456, $1355 \mathrm{~cm}^{-1}$. EIMS m/z (\%) 441/443 (25, $\mathrm{M}^{+}$), 422 (2), 336 (2), 318 (5), 281 (2), 207 (5), 167 (10), 140 (1), 105 (100), 77 (30). Anal. calcd for $\mathrm{C}_{27} \mathrm{H}_{20} \mathrm{ClNO}_{3}$ (441.91): C, 73.38; H, 4.56; N, 3.17. Found: C, 73.22; H, 4.41; N. 3.31\%.

Major isomer 7d. ${ }^{1} \mathrm{H}$ NMR $\delta 2.35\left(\mathrm{~s}, 3 \mathrm{H}, \mathrm{CH}_{3}\right), 2.97-3.10(\mathrm{~m}, 2 \mathrm{H}, 12-\mathrm{H}), 3.15-3.23(\mathrm{~m}, 1 \mathrm{H}$, 12a-H), 3.35-3.40 (m, 2H, 6-H), 4.98-5.02 (m, 1H, 5a-H), 6.85 (d, J=0.4 Hz, 1H, 4-H), 6.854 (ddd, $J=8.4,1.0,0.5 \mathrm{~Hz}, 1 \mathrm{H}, 8-\mathrm{H}), 7.031$ (ddd, $J=8.4,7.3,1.3 \mathrm{~Hz}, 1 \mathrm{H}, 9-\mathrm{H}), 7.168$ (ddd, $J=$ 7.7, 7.3, 1.0 Hz, 1H, 10-H), 7.386 (ddd, $J=7.7,1.3,0.5 \mathrm{~Hz}, 1 \mathrm{H}, 11-\mathrm{H}), 7.51-7.55$ (m, 2H, 3',5'H), 7.62-7.69 (m, 1H, 4'-H ), 7.71-7.75 (m, 2H, 2',6'-H), $7.891(\mathrm{~d}, J=0.4 \mathrm{~Hz}, 1 \mathrm{H}, 1-\mathrm{H}) .{ }^{13} \mathrm{C}$ NMR $\left(75 \mathrm{MHz}, \mathrm{CDCl}_{3}\right) \delta 19.25(\mathrm{C}-12), 20.87\left(3-\mathrm{CH}_{3}\right), 29.88(\mathrm{C}-6), 44.01(\mathrm{C}-12 \mathrm{a}), 75.64(\mathrm{C}-$ 5a), 114.69 (C-8), 115.74 (C-11b), 117.88 (C-13a), 118.11 (C-11), 120.07 (C-4), 122.95 (C-10), 123.62 (C-9), 127.24 (C-1), 127.97 (C-2), 128.83 (C-3',5'), 129.08 (C-11a), 129.13 (C-2',6'), 131.79 (C-6a), 132.75 (C-4'), 135.41 (C-1'), 136.59 (C-7a), 145.26 (C-3), 159.11 (C-4a), 169.11 (7-CO), 193.30 (C-13).

Some NMR data for the minor isomer 8d were also deduced: ${ }^{1} \mathrm{H}$ NMR $\delta 2.37\left(\mathrm{~s}, 1 \mathrm{H}, \mathrm{CH}_{3}\right)$, 5.05-5.10 (m, 1H, 5a-H), 6.88 (d, $J=0.45 \mathrm{~Hz}, 1 \mathrm{H}, 4-\mathrm{H}), 7.05$ (ddd, $J=8.4,7.3,1.3 \mathrm{~Hz}, 1 \mathrm{H}, 9$ $\mathrm{H}), 7.18(\mathrm{ddd}, J=7.7,7.3,1.0 \mathrm{~Hz}, 1 \mathrm{H}, 8-\mathrm{H}), 7.84(\mathrm{~s}, 1 \mathrm{H}, 1-\mathrm{H}) .{ }^{13} \mathrm{C}$ NMR $\left(75 \mathrm{MHz}, \mathrm{CDCl}_{3}\right) \delta$ 17.94 (C-12), $22.68\left(3-\mathrm{CH}_{3}\right), 25.27$ (C-6), 45.04 (C-12a), 75.19 (C-5a), 113.35 (C-10), 114.70 (C-6a), 118.41 (C-7), 118.64 (C-13a), 120.12 (C-4), 122.81 (C-8), 123.67 (C-9), 127.15 (C-1), 127.84 (C-2), 128.80 (C-3',5'), 129.10 (C-6b), 129.15 (C-2',6'), 132.42 (C-11a), 132.80 (C-4'), 135.31 (C-1'), 136.78 (C-10a), 145.25 (C-3), 159.11 (C-4a), 169.11 (7-CO), 193.30 (C-13).

\section{From compound $3 \mathrm{e}$}

$(5 \mathrm{a} R, 12 \mathrm{a} R$ or $5 \mathrm{a} S, 12 \mathrm{a} S)-7-B e n z o y l-2-n i t r o-6,7,12,12 \mathrm{a}-$ tetrahydrochromeno[2,3-b]carbazol13(5aH)-one (5e) and $(5 \mathrm{a} R, 12 \mathrm{a} R$ or 5aS,12aS)-11-benzoyl-2-nitro-6,11,12,12atetrahydrochromeno $[3,2-b]$ carbazol-13(5aH)-one (6e) in a 10:1 ratio. $0.118 \mathrm{~g}, 27 \%$ Yield, white solid, mp 236-242 ${ }^{\circ} \mathrm{C}(\mathrm{EtOH})$; IR (KBr) $v_{\max }: 1698,1681,1615,1519,1343,1278 \mathrm{~cm}^{-1}$. EIMS m/z (\%) 393 (4, M ${ }^{+}$), 288 (40), 105 (45), 104 (62), 77 (100). Anal. calcd for $\mathrm{C}_{26} \mathrm{H}_{18} \mathrm{~N}_{2} \mathrm{O}_{5}$ (438.43): C, 71.23; H, 4.14; N, 6.39. Found: C, 71.49; H, 4.02; N. 6.25\%. 
Major isomer 5e: ${ }^{1} \mathrm{H}$ NMR $\delta 2.885$ (dddd, $J=17.2,10.7,3.0,1.7 \mathrm{~Hz}, 1 \mathrm{H}, 12-\mathrm{H}_{\mathrm{ax}}$ ), 3.159 (ddd, $J$ $\left.=13.3,10.7,6.1, \mathrm{~Hz}, 1 \mathrm{H}, 12 \mathrm{a}-\mathrm{H}_{\mathrm{ax}}\right), 3.405$ (dddd, $\left.J=17.1,9.3,3.0,1.7 \mathrm{~Hz}, 1 \mathrm{H}, 6-\mathrm{H}_{\mathrm{ax}}\right), 3.524$ (dddd, $J=17.2,6.1,1.7,0.5 \mathrm{~Hz}, 1 \mathrm{H}, 12-\mathrm{H}_{\mathrm{eq}}$ ), 3.609 (dddd, $J=17.1,6.1,1.7,0.5 \mathrm{~Hz}, 1 \mathrm{H}, 6-\mathrm{H}_{\mathrm{eq}}$ ), $4.751\left(\mathrm{ddd}, J=13.3,9.3,6.1 \mathrm{~Hz}, 1 \mathrm{H}, 5 \mathrm{a}-\mathrm{H}_{\mathrm{ax}}\right), 6.906$ (ddd, $\left.J=8.4,1.1,0.4 \mathrm{~Hz}, 1 \mathrm{H}, 8-\mathrm{H}\right), 7.068$ (ddd, $J=8.4,7.3,1.2 \mathrm{~Hz}, 1 \mathrm{H}, 9-\mathrm{H}), 7.139$ (dd, $J=9.1,0.4 \mathrm{~Hz}, 1 \mathrm{H}, 4-\mathrm{H}), 7.215$ (ddd, $J=7.8$, 7.3, $1.0 \mathrm{~Hz}, 1 \mathrm{H}, 10-\mathrm{H}), 7.508$ (ddd, $J=7.8,1.2,0.4 \mathrm{~Hz}, 1 \mathrm{H}, 11-\mathrm{H}), 7.49-7.56$ (m, 2H, 3',5'-H), 7.661 (tt, $\left.J=7.5,1.35 \mathrm{~Hz}, 1 \mathrm{H}, 4^{\prime}-\mathrm{H}\right), 7.71-7.75$ (m, 2H, 2',6'-H), 8.344 (dd, $J=9.1,2.85 \mathrm{~Hz}, 1 \mathrm{H}$, $3-\mathrm{H}), 8.835(\mathrm{dd}, J=2.85,0.4 \mathrm{~Hz}, 1 \mathrm{H}, 1-\mathrm{H}) .{ }^{13} \mathrm{C} \mathrm{NMR}\left(75 \mathrm{MHz}, \mathrm{CDCl}_{3}\right) \delta 19.76(\mathrm{C}-12), 31.96$ (C-6), 45.73 (C-12a), 78.90 (C-5a), 114.83 (C-8), 115.63 (C-11b), 118.49 (C-11), 119.31 (C-4), 120.46 (C-13a), 123.23 (C-10), 123.88 (C-9), 124.05 (C-1), 128.86 (C-11a), 128.99 (C-3',5'), 129.57 (C-2',6'), 130.46 (C-3), 131.20 (C-6a), 132.96 (C-4'), 135.52 (C-1'), 137.28 (C-7a), 142.77 (C-2), 165.09 (C-4a), 169.01 (7-CO), 191.38 (C-13).

Some NMR data of the minor isomer 6e were also deduced: ${ }^{1} \mathrm{H}$ NMR $\delta 7.03$ (ddd, $J=8.4,7.2$, $1.2 \mathrm{~Hz}, 1 \mathrm{H}, 9-\mathrm{H}), 7.166$ (dd, $J=9.1,0.38 \mathrm{~Hz}, 1 \mathrm{H}, 4-\mathrm{H}), 8.351$ (dd, $J=9.1,2.85 \mathrm{~Hz}, 1 \mathrm{H}, 3-\mathrm{H})$, $8.793(\mathrm{dd}, J=2.85,0.38 \mathrm{~Hz}, 1 \mathrm{H}, 1-\mathrm{H}),{ }^{13} \mathrm{C} \mathrm{NMR}\left(75 \mathrm{MHz}, \mathrm{CDCl}_{3}\right) \delta 24.09(\mathrm{C}-12), 28.08(\mathrm{C}-6)$, 46.54 (C-12a), 78.58 (C-5a), 114.92 (C-10), 116.20 (C-6a), 118.04 (C-7), 119.20 (C-4), 123.07 (C-8), 123.95 (C-9), 124.05 (C-1), 128.99 (C-3',5'), 129.57 (C-2',6'), 130.30 (C-3), 133.00 (C-4'), 142.30 (C-2), 168.5 (7-CO).

$(5 \mathrm{a} R, 12 \mathrm{a} S$ or $5 \mathrm{a} S, 12 \mathrm{a} R)-7-B e n z o y l-5-n i t r o-6,7,12,12 \mathrm{a}-$ tetrahydrochromeno[2,3-b]carbazol$13(5 \mathrm{a} H)$-one (7e) and $(5 \mathrm{a} S, 12 \mathrm{a} R$ or $5 \mathrm{a} R, 12 \mathrm{a} S)-11-b e n z o y l-5-n i t r o-6,11,12,12 \mathrm{a}-$ tetrahydrochromeno $[3,2-b]$ carbazol-13(5aH)-one (8e) in a 3:1 ratio. $0.259 \mathrm{~g}, 59 \%$ Yield, white solid, mp 227-232 ${ }^{\circ} \mathrm{C}(\mathrm{EtOH})$; IR (KBr) $v_{\max }$ : 1705, 1683, 1614, 1585, 1515, 1338, 1273 $\mathrm{cm}^{-1}$. EIMS m/z (\%) $393\left(4, \mathrm{M}^{+}\right)$), 288 (40), 105 (45), 104 (62), 77 (100). Anal. calcd for $\mathrm{C}_{26} \mathrm{H}_{18} \mathrm{~N}_{2} \mathrm{O}_{5}$ (438.43): C, 71.23; H, 4.14; N, 6.39. Found: C, 71.39; H, 4.22; N. 6.47\%.

Major isomer 7e. $\mathrm{mp} 234-236{ }^{\circ} \mathrm{C}(\mathrm{EtOH}) ;{ }^{1} \mathrm{H} \mathrm{NMR} \delta 3.010(\mathrm{ddd}, J=9.4,1.3,0.5 \mathrm{~Hz}, 1 \mathrm{H}, 12-$ $\mathrm{H}_{\mathrm{ax}}, 3.040$ (ddd, $J=6.7,1.3,0.5 \mathrm{~Hz}, 1 \mathrm{H}, 12-\mathrm{H}_{\mathrm{eq}}, 3.222$ (ddd, $J=9.4,6.7,2.7 \mathrm{~Hz}, 1 \mathrm{H}, 12 \mathrm{a}-\mathrm{H}_{\mathrm{ax}}$ ), $3.443\left(\mathrm{ddd}, J=4.2,1.3,0.5 \mathrm{~Hz}, 1 \mathrm{H}, 6-\mathrm{H}_{\mathrm{ax}}\right), 3.451$ (ddd, $\left.J=4.5,1.3,0.5 \mathrm{~Hz}, 1 \mathrm{H}, 6-\mathrm{H}_{\mathrm{eq}}\right), 5.168$ (ddd, $\left.J=4.5,4.2,2.7 \mathrm{~Hz}, 1 \mathrm{H}, 5 \mathrm{a}-\mathrm{H}_{\mathrm{eq}}\right), 6.812$ ( ddd, $\left.J=8.4,1.0,0.6 \mathrm{~Hz}, 1 \mathrm{H}, 8-\mathrm{H}\right), 7.042$ (ddd, $J$ $=8.4,7.2,1.1 \mathrm{~Hz}, 1 \mathrm{H}, 9-\mathrm{H}), 7.103(\mathrm{~d}, J=9.1,1 \mathrm{H}, 4-\mathrm{H}), 7.183(\mathrm{ddd}, J=7.9,7.2,1.0 \mathrm{~Hz}, 1 \mathrm{H}, 10-$ H), 7.402 (ddd, $J=7.9,1.1,0.6 \mathrm{~Hz}, 1 \mathrm{H}, 11-\mathrm{H}), 7.529$ (ddd, $\left.J=8.2,7.4,1.5 \mathrm{~Hz}, 2 \mathrm{H}, 3^{\prime}, 5^{\prime}-\mathrm{H}\right)$, 7.663 (tt, $\left.J=7.4,1.5 \mathrm{~Hz}, 1 \mathrm{H}, 4^{\prime}-\mathrm{H}\right), 7.741$ (ddd, $\left.J=8.2,2.0,1.3 \mathrm{~Hz}, 2 \mathrm{H}, 2^{\prime}, 66^{\prime}-\mathrm{H}\right), 8.345$ (dd, $J=$ 9.1, $2.8 \mathrm{~Hz}, 1 \mathrm{H}, 3-\mathrm{H}), 8.848(\mathrm{~d}, J=2.8 \mathrm{~Hz}, 1 \mathrm{H}, 1-\mathrm{H}) .{ }^{13} \mathrm{C} \mathrm{NMR}\left(75 \mathrm{MHz}, \mathrm{CDCl}_{3}\right) \delta 19.05(\mathrm{C}-$ 12), 29.58 (C-6), 43.96 (C-12a), 76.58 (C-5a), 114.75 (C-8), 115.32 (C-11b), 118.18 (C-11), 118.44 (C-13a), 119.18 (C-11a), 119.38 (C-4), 123.08 (C-9), 123.86 (C-10), 124.20 (C-1), 128.92 (C-3',5'), 129.51 (C-2',6'), 130.50 (C-3), 131.33 (C-6a), 132.92 (C-4'), 135.30 (C-1'), 136.67 (C-7a), 142.58 (C-2), 164.72 (C-4a), 169.12 (7-CO), 192.19 (C-13).

General procedure for the Diels-Alder reactions of 3-formylchromones (3a-3e) with pyrazole o-quinodimethane 10

To a stirred solution of the chromone $3(5.0 \mathrm{mmol})$ in dry toluene $(25 \mathrm{~mL}), 18$-crown- 6 ether was added $(0.581 \mathrm{~g}, 2.2 \mathrm{mmol})$ followed by the addition of 1-benzoyl-3-phenyl-4,5- 
bis(bromomethyl)pyrazole (9) $(0.434 \mathrm{~g}, 1.0 \mathrm{mmol})$ and finally sodium iodide $(0.33 \mathrm{~g}, 2.2 \mathrm{mmol})$ and the reaction mixture was stirred at reflux under nitrogen for $10 \mathrm{~h}$. The solvent was distilled off and from the resulting residue the excess of chromone was removed, as described previously. The residue was finally purified by column chromatography on silica gel using petroleum ether/EtOAc $(7: 1)$ as eluent, to give in order of elution the chromenoindazole 13, the trans tetrahydrochromenoindazole $\mathbf{1 1}$ followed by the cis isomer $\mathbf{1 2}$.

\section{From compound 3a}

1-Benzoyl-3-phenylchromeno[3,2-f] indazol-5(1H)-one (14a). 0.146 g, 35\% Yield. White solid $\left(\mathrm{CH}_{2} \mathrm{Cl}_{2}-\mathrm{Et}_{2} \mathrm{O}\right), \operatorname{mp} 232-234{ }^{\circ} \mathrm{C}$; IR (KBr) $v_{\max }: 1691,1654,1623,1469,1339 \mathrm{~cm}^{-1} .{ }^{1} \mathrm{H}$ NMR $\delta$ 7.442 (ddd, $J=8.0,7.1,1.1 \mathrm{~Hz}, 1 \mathrm{H}, 7-\mathrm{H}), 7.53-7.63$ (m, 6H, 3',4',5',3",4",5"-H), 7.639 (dd, $J=$ 8.4, 1.1 Hz, 1H, 9-H), 7.805 (ddd, $J=8.4,7.1,1.7 \mathrm{~Hz}, 1 \mathrm{H}, 8-\mathrm{H}), 8.06-8.10$ (m, 2H, 2",6"-H), 8.22-8.26 (m, 2H, 2',6'-H), 8.407 (ddd, $J=8.0,1.7,0.4 \mathrm{~Hz}, 1 \mathrm{H}, 6-\mathrm{H}), 8.790$ (d, $J=0.6 \mathrm{~Hz}, 1 \mathrm{H}$, 4-H), 9.099 (d, $J=0.6 \mathrm{~Hz}, 1 \mathrm{H}, 11-\mathrm{H}) .{ }^{13} \mathrm{C}$ NMR $\left(75 \mathrm{MHz}, \mathrm{CDCl}_{3}\right) \delta 104.44(\mathrm{C}-11), 118.13(\mathrm{C}-$ 9), 120.18 (C-3a), 121.23 (C-4a), 121.39 (C-7), 121.90 (C-5a), 124.21 (C-4), 127.00 (C-6), 128.10 (C-3",5"), 128.37 (C-3',5'), 129.22 (C-2",6"), 130.22 (C-4"), 130.92 (C-1"), 131.49 (C2',6'), 132.65 (C-4'), 132.88 (C-1'), 135.42 (C-8), 144.22 (C-11a), 151.30 (C-3), 156.59 (C-10a), 156.69 (C-9a), 168.22 (1-CO), 177.42 (C-5). EIMS m/z (\%) 416 (40, M⿻), 388 (2), 339 (2), 311 (5), 283 (8), 255 (4), 226 (12), 200 (3), 105 (100), 77 (30). Anal. calcd for $\mathrm{C}_{27} \mathrm{H}_{16} \mathrm{~N}_{2} \mathrm{O}_{3}(416.43$ ): C, 77.87; H, 3.87; N, 6.73. Found: C, 77.69; H, 4.01; N. 6.85\%.

(4aS,10aR or 4aR,10aS)-1-Benzoyl-3-phenyl-4,4a,10a,11-tetrahydrochromeno[3,2-f]indazol5(1H)-one (12a). $0.084 \mathrm{~g}, 20 \%$ Yield. White solid $\left(\mathrm{CH}_{2} \mathrm{Cl}_{2}-\mathrm{Et}_{2} \mathrm{O}\right), \mathrm{mp} 234-236{ }^{\circ} \mathrm{C}$; IR ( $\left.\mathrm{KBr}\right)$ $v_{\text {max }}: 1682,1661,1620 \mathrm{~cm}^{-1} .{ }^{1} \mathrm{H}$ NMR $\delta 2.95-3.06(\mathrm{~m}, 2 \mathrm{H}, 4-\mathrm{H}), 3.30-3.40(\mathrm{~m}, 1 \mathrm{H}, 4 \mathrm{a}-\mathrm{H}), 3.73$ $\left(\mathrm{dm}, J=18.2 \mathrm{~Hz}, 1 \mathrm{H}, 11-\mathrm{H}_{\mathrm{ax}}\right), 4.768\left(\mathrm{dm}, J=18.2 \mathrm{~Hz}, 1 \mathrm{H}, 11-\mathrm{H}_{\mathrm{eq}}\right), 5.22-5.23(\mathrm{~m}, 1 \mathrm{H}, 10 \mathrm{a}-\mathrm{H})$, 7.39-7.51 (m, 6H, 9,3', 5',3",4",5"-H), 7.51-7.66 (m, 2H, 6,4'), 7.784 (ddd, J = 8.4, 7.2, 1.7 Hz, 1H, 7-H), 7.78-7.83 (m, 1H, 8-H), 7.87-7.90 (m, 2H, 2",6"-H), 8.13-8.16 (m, 2H, 2',6'-H). ${ }^{13} \mathrm{C}$ NMR (75 MHz, $\left.\mathrm{CDCl}_{3}\right) \delta 20.90(\mathrm{C}-4), 31.55$ (C-11), 45.82 (C-4a), 65.88 (C-10a), $116.84(\mathrm{C}-9)$, 119.61 (C-5a), 119.78 (C-3a), 120.08 (C-7), 126.92 (C-6), 127.48 (C-2",6"), 127.97 (C-3',5'), 128.33 (C-3",5"), 128.81 (C-4"), 131.48 (C-1"), 131.75 (C-2',6'), 131.96 (C-1'), 132.79 (C-4'), 140.25 (C-11a), 140.25 (C-8), 152.16 (C-3), 159.53 (C-9a), 168.00 (1-CO), 191.88 (C-5). EIMS $\mathrm{m} / \mathrm{z}(\%) 420\left(22, \mathrm{M}^{+}\right.$), 402 (5), 388 (2), 339 (5), 315 (18), 297 (14), 281 (4), 207 (12), 195 (10), 165 (9), 121 (4), 105 (100), 77 (50). Anal. calcd for $\mathrm{C}_{27} \mathrm{H}_{20} \mathrm{~N}_{2} \mathrm{O}_{3}$ (420.46): C, 77.13; H, 4.79; N, 6.66. Found: C, 77.39; H, 4.91; N. 6.80\%.

\section{From compound 3b}

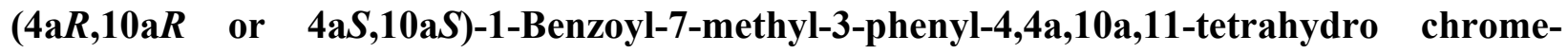
no[3,2-f]indazol-5(1H)-one (11b). $0.126 \mathrm{~g}, 29 \%$ Yield. White solid $\left(\mathrm{CH}_{2} \mathrm{Cl}_{2}-\mathrm{Et}_{2} \mathrm{O}\right)$, mp $240-$ $242{ }^{\circ} \mathrm{C}$; IR (KBr) v $v_{\text {max }}: 1680,1620,1606 \mathrm{~cm}^{-1} .{ }^{1} \mathrm{H}$ NMR $\delta 2.370\left(\mathrm{~s}, 3 \mathrm{H}, 7-\mathrm{CH}_{3}\right), 2.870$ (dddd, $J=$ $\left.17.7,10.9,3.3,1.1 \mathrm{~Hz}, 1 \mathrm{H}, 4-\mathrm{H}_{\mathrm{ax}}\right), 3.028$ (ddd, $\left.J=13.1,10.9,6.5 \mathrm{~Hz}, 1 \mathrm{H}, 4 \mathrm{a}-\mathrm{H}\right), 3.46-3.52$ (m, $\left.1 \mathrm{H}, 11-\mathrm{H}_{\mathrm{ax}}\right), 3.52-3.56\left(\mathrm{~m}, 1 \mathrm{H}, 4-\mathrm{H}_{\mathrm{eq}}\right), 4.090\left(\mathrm{ddd}, J=17.7,6.1,1.7 \mathrm{~Hz}, 1 \mathrm{H}, 11-\mathrm{H}_{\mathrm{eq}}\right), 4.694$ 
(ddd, $J=13.1,9.4,6.1 \mathrm{~Hz}, 1 \mathrm{H}, 10 \mathrm{a}-\mathrm{H}), 6.981$ (d, $J=8.5 \mathrm{~Hz}, 1 \mathrm{H}, 9-\mathrm{H}), 7.359$ (dd, $J=8.5,2.7$ Hz, 1H, 8-H), 7.40-7.49 (m, 3H, 3",4",5"-H), 7.50-7.54 (m, 2H, 3',5'-H), 7.615 (tt, $J=7.5,1.4$ $\left.\mathrm{Hz}, 1 \mathrm{H}, 4^{\prime}-\mathrm{H}\right), 7.753$ (dd, $\left.J=2.2,0.5 \mathrm{~Hz}, 1 \mathrm{H}, 6-\mathrm{H}\right), 7.78-7.82$ (m, 2H, 2",6"-H), 8.13-8.17 (m, $\left.2 \mathrm{H}, 2^{\prime}, 6^{\prime}-\mathrm{H}\right) .{ }^{13} \mathrm{C}$ NMR $\left(75 \mathrm{MHz}, \mathrm{CDCl}_{3}\right) \delta 20.36(\mathrm{C}-4), 20.49\left(7-\mathrm{CH}_{3}\right), 31.62(\mathrm{C}-11), 44.94(\mathrm{C}-$ 4a), 78.10 (C-10a), 116.70 (C-3a), 117.86 (C-9), 119.82 (C-5a), 127.21 (C-6), 127.50 (C-2",6"), 127.95 (C-3',5'), 128.69 (C-3",5"), 129.01 (C-4"), 131.36 (C-7), 131.50 (C-1"), 131.71 (C-2',6'), 132.73 (C-4'), 132.80 (C-1'), 137.40 (C-8), 140.46 (C-11a), 152.15 (C-3), 159.35 (C-9a), 168.20 (1-CO), 192.02 (C-5). EIMS m/z (\%) 430 (25, $\left.\mathrm{M}^{+} \cdot-2 \mathrm{H}_{2}\right),{ }^{23} 325$ (2), 297 (5), 281 (3), 239 (6), 207 (5), 105 (100), 77 (35). Anal. calcd for $\mathrm{C}_{28} \mathrm{H}_{22} \mathrm{~N}_{2} \mathrm{O}_{3}$ (434.49): C, 77.40; H, 5.10; N, 6.45. Found: C, 77.27; H, 5.12; N. 6.42\%.

(4aS,10aR or 4aR,10aS)-1-Benzoyl-7-methyl-3-phenyl-4,4a,10a,11-tetrahydrochromeno[3,2flindazol-5(1H)-one (12b). $0.056 \mathrm{~g}, 13 \%$ Yield. White solid $\left(\mathrm{CH}_{2} \mathrm{Cl}_{2}-\mathrm{Et}_{2} \mathrm{O}\right), \mathrm{mp} 236-238^{\circ} \mathrm{C}$; IR (KBr) $v_{\max }: 1684,1644,1605,1477,1457,1359 \mathrm{~cm}^{-1} .{ }^{1} \mathrm{H}$ NMR $\delta 2.342\left(\mathrm{~s}, 3 \mathrm{H}, \mathrm{CH}_{3}\right), 2.93-3.02$ (m, 2H, 4-H), 3.03-3.05 (m, 1H, 4a-H), 3.590 (dd, $J=19.3,5.2 \mathrm{~Hz}, 1 \mathrm{H}, 11-\mathrm{H}), 3.837$ (dd, $J=$ $19.3,2.5 \mathrm{~Hz}, 1 \mathrm{H}, 11-\mathrm{H}), 5.060$ (ddd, $J=5.2,2.8,2.5 \mathrm{~Hz}, 1 \mathrm{H}, 10 \mathrm{a}-\mathrm{H}), 6.930$ (d, $J=8.5 \mathrm{~Hz}, 1 \mathrm{H}, 9-$ H), 7.344 (dd, $J=8.3,2.0 \mathrm{~Hz}, 1 \mathrm{H}, 8-\mathrm{H}), 7.35-7.40$ (m, 2H, 3",5"-H), 7.43-7.48 (m, 1H, 4"-H), 7.48-7.54 (m, 2H, 3',5'-H), 7.612 (tt, $\left.J=7.4,1.4 \mathrm{~Hz}, 1 \mathrm{H}, 4^{\prime}-\mathrm{H}\right), 7.68-7.71$ (m, 2H, 2",6"-H), $7.750(\mathrm{~d}, J=2.0 \mathrm{~Hz}, 1 \mathrm{H}, 6-\mathrm{H}), 8.13-8.17\left(\mathrm{~m}, 2 \mathrm{H}, 2^{\prime}, 66^{\prime}-\mathrm{H}\right) .{ }^{13} \mathrm{C} \mathrm{NMR}\left(75 \mathrm{MHz}, \mathrm{CDCl}_{3}\right) \delta 20.50$ (C-4), $20.75\left(\mathrm{CH}_{3}\right), 29.73$ (C-11), 46.07 (C-4a), 75.86 (C-10a), 116.85 (C-3a), 117.87 (C-9), 121.02 (C-5a), 127.21 (C-6), 127.52 (C-2",6"), 127.95 (C-3',5'), 128.08 (C-1"), 128.80 (C-3",5"), 129.02 (C-4"), 131.45 (C-7), 131.71 (C-2',6'), 132.61 (C-4'), 132.75 (C-1'), 137.47 (C-8), 140.42 (C-11a), 152.13 (C-3), 159.40 (C-9a), 171.80 (1-CO), 193.20 (C-5). EIMS m/z (\%) 434 (25, $\mathrm{M}^{+}$), 329 (60), 311 (30), 239 (5), 195 (7), 165 (12), 135 (10), 105 (100), 77 (40). Anal. calcd for $\mathrm{C}_{28} \mathrm{H}_{22} \mathrm{~N}_{2} \mathrm{O}_{3}$ (434.49): C, 77.40; H, 5.10; N, 6.45. Found: C, 77.27; H, 5.12; N. 6.42.

\section{From compound 3c}

(4aR,10a $R$ or 4aS,10aS)-1-Benzoyl-7-chloro-3-phenyl-4,4a,10a,11-tetrahydrochromeno[3,2flindazol-5(1H)-one (11c). $0.091 \mathrm{~g}, 20 \%$ Yield. White solid $\left(\mathrm{CH}_{2} \mathrm{Cl}_{2}-\mathrm{Et}_{2} \mathrm{O}\right), \mathrm{mp} 226-228{ }^{\circ} \mathrm{C}$. IR $(\mathrm{KBr}) v_{\max }: 1681,1636,1465 \mathrm{~cm}^{-1} .{ }^{1} \mathrm{H}$ NMR $\delta 2.871$ (dddd, $J=16.4,10.5,2.5,1.6 \mathrm{~Hz}, 1 \mathrm{H}$, 4$\mathrm{H}_{\mathrm{ax}}$ ), 3.034 (ddd, $\left.J=13.3,11.0,5.4 \mathrm{~Hz}, 1 \mathrm{H}, 4 \mathrm{a}-\mathrm{H}_{\mathrm{ax}}\right), 3.48-3.56\left(\mathrm{~m}, 2 \mathrm{H}, 4-\mathrm{H}_{\mathrm{eq}}, 11-\mathrm{H}_{\mathrm{ax}}\right), 4.098$ (ddd, $J=17.7,6.4,1.6 \mathrm{~Hz}, 1 \mathrm{H}, 11-\mathrm{H}_{\mathrm{eq}}$ ), 4.714 (ddd, $J=13.3,9.7,6.4 \mathrm{~Hz}, 1 \mathrm{H}, 10 \mathrm{a}-\mathrm{H}_{\mathrm{ax}}$ ), 7.042 (d, $J=9.1 \mathrm{~Hz}, 1 \mathrm{H}, 9-\mathrm{H}), 7.40-7.65$ (m, 6H, 8,3',5',3",4",5"-H), 7.75-7.83 (m, 2H, 2",6"-H), $7.914(\mathrm{~d}, J=2.9 \mathrm{~Hz}, 1 \mathrm{H}, 6-\mathrm{H}), 8.03-8.12\left(\mathrm{~m}, 1 \mathrm{H}, 4{ }^{\prime}-\mathrm{H}\right), 8.13-8.20$ (m, 2H, 2',6'-H). ${ }^{13} \mathrm{C}$ NMR $\left(75 \mathrm{MHz}, \mathrm{CDCl}_{3}\right) \delta 20.66(\mathrm{C}-4), 31.54$ (C-11), 45.90 (C-4a), 77.33 (C-10a), 116.74 (C-3a), 119.79 (C-9), 121.20 (C-5a), 126.61 (C-6), 127.50 (C-2",6"), 127.99 (C-3',5'), 128.20 (C-7), 128.84 (C-3",5"), 129.10 (C-4"), 131.50 (C-1"), 131.75 (C-2',6'), 131.98 (C-1'), 132.81 (C-4'), 136.16 (C-8), 140.20 (C-11a), 152.17 (C-3), 159.72 (C-9a), 168.05 (1-CO), 192.06 (C-5). EIMS $\mathrm{m} / \mathrm{z}(\%)$ 454/456 (10, $\mathrm{M}^{+}$), 349/351 (16), 105 (100). Anal. calcd for $\mathrm{C}_{27} \mathrm{H}_{19} \mathrm{ClN}_{2} \mathrm{O}_{3}$ (454.90): C, 71.29; H, 4.21; N, 6.16. Found: C, 71.51; H, 4.35; N, 6.19\%. 
(4aS,10aR or 4aR,10aS)-1-Benzoyl-7-chloro-3-phenyl-4,4a,10a,11-tetrahydrochromeno[3,2flindazol-5(1H)-one (12c). $0.141 \mathrm{~g}, 31 \%$ Yield. White solid $\left(\mathrm{CH}_{2} \mathrm{Cl}_{2}-\mathrm{Et}_{2} \mathrm{O}\right), \mathrm{mp} 202-204{ }^{\circ} \mathrm{C}$; IR (KBr) $v_{\max }: 1684,1632 \mathrm{~cm}^{-1} .{ }^{1} \mathrm{H}$ NMR $\delta 2.95-3.06(\mathrm{~m}, 3 \mathrm{H}, 4,4 \mathrm{a}-\mathrm{H}), 3.603$ (ddd, $J=19.2,4.8$, $\left.0.8 \mathrm{~Hz}, 1 \mathrm{H}, 11-\mathrm{H}_{\mathrm{ax}}\right), 3.842\left(\mathrm{ddd}, J=19.2,1.4,1.0 \mathrm{~Hz}, 1 \mathrm{H}, 11-\mathrm{H}_{\mathrm{eq}}\right), 5.081$ (ddd, $J=4.8,3.5,1.4$ $\mathrm{Hz}, 1 \mathrm{H}, 10 \mathrm{a}-\mathrm{H}), 6.993$ (d, $J=8.9 \mathrm{~Hz}, 1 \mathrm{H}, 9-\mathrm{H}), 7.37-7.53$ (m, 1H, 9-H), 7.38-7.42 (m, 3H, 3",4",5"-H), 7.465 (dd, $J=8.9,2.4 \mathrm{~Hz}, 1 \mathrm{H}, 8-\mathrm{H}), 7.48-7.53$ (m, 2H, 3',5'-H), 7.611 (tt, $J=7.5$, $\left.1.3 \mathrm{~Hz}, 1 \mathrm{H}, 4^{\prime}-\mathrm{H}\right), 7.65-7.71$ (m, 2H, 2",6"-H), 7.912 (d, J=2.4 Hz, 1H, 6-H), 8.13-8.16 (m, 2H, $\left.2^{\prime}, 6{ }^{\prime}-\mathrm{H}\right) .{ }^{13} \mathrm{C}$ NMR $\left(75 \mathrm{MHz}, \mathrm{CDCl}_{3}\right) \delta 20.20$ (C-4), 31.01 (C-11), 44.63 (C-4a), 75.06 (C-10a), 116.61 (C-3a), 119.84 (C-9), 120.18 (C-5a), 126.99 (C-6), 127.52 (C-2",6"), 127.67 (C-7), 127.98 (C-3',5'), 128.74 (C-3",5"), 129.04 (C-4"), 131.67 (C-2',6'), 131.96 (C-1"), 132.54 (C-1'), 132.81 (C-4'), 136.22 (C-8), 140.00 (C-11a), 152.21 (C-3), 159.20 (C-9a), 168.08 (1-CO), 193.12 (C-5). EIMS m/z (\%) 454/456 (5, M+*), 349/351 (8), 331/333 (3), 281 (4), 207 (8), 165 (5), 105 (100). Anal. calcd for $\mathrm{C}_{27} \mathrm{H}_{19} \mathrm{ClN}_{2} \mathrm{O}_{3}$ (454.90): C, 71.29; H, 4.21; N, 6.16. Found: C, 71.55; H, 4.10; N, 6.27.

\section{From compound 3d}

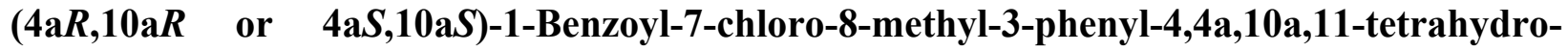
chromeno[3,2-f] indazol-5(1H)-one (11d). $0.084 \mathrm{~g}, 18 \%$ Yield. White solid $\left(\mathrm{CH}_{2} \mathrm{Cl}_{2}-\mathrm{Et}_{2} \mathrm{O}\right), \mathrm{mp}$ 219-221 ${ }^{\circ} \mathrm{C}$; IR (KBr) $v_{\max }: 1688,1661,1622,1466,1335 \mathrm{~cm}^{-1} .{ }^{1} \mathrm{H}$ NMR $\delta 2.418$ (s, 3H, 8$\mathrm{CH}_{3}$ ), 2.865 (dddd, $J=16.3,10.9,2.8,1.0 \mathrm{~Hz}, 1 \mathrm{H}, 4-\mathrm{H}_{\mathrm{ax}}$ ), 3.009 (ddd, $J=13.3,10.9,5.1 \mathrm{~Hz}$, $1 \mathrm{H}, 4 \mathrm{a}-\mathrm{H}_{\mathrm{ax}}$ ), 3.510 (dddd, $\left.J=17.5,9.6,2.8,0.5 \mathrm{~Hz}, 1 \mathrm{H}, 11-\mathrm{H}_{\mathrm{ax}}\right), 3.514$ (ddd, $J=16.3,5.1,0.5$ $\mathrm{Hz}, 1 \mathrm{H}, 4-\mathrm{H}_{\mathrm{eq}}$ ), 4.081 (ddd, $\left.J=17.5,6.3,1.0 \mathrm{~Hz}, 1 \mathrm{H}, 11-\mathrm{H}_{\mathrm{eq}}\right), 4.688$ (ddd, $J=13.3,9.6,6.3 \mathrm{~Hz}$, 1H, 10a-H), 6.975 ( d, $J=0.5 \mathrm{~Hz}, 1 \mathrm{H}, 9-\mathrm{H}), 7.42-7.50$ (m, 3H, 3",4",5"-H), 7.51-7.55 (m, 2H, 3',5'-H), 7.619 (tt, $\left.J=7.6,1.8 \mathrm{~Hz}, 1 \mathrm{H}, 4^{\prime}-\mathrm{H}\right), 7.77-7.82$ (m, 2H, 2",6"-H), 7.902 (d, $J=0.5 \mathrm{~Hz}$, $1 \mathrm{H}, 6-\mathrm{H}), 8.13-8.17$ (m, 2H, 2',6'-H). ${ }^{13} \mathrm{C} \mathrm{NMR}\left(75 \mathrm{MHz}, \mathrm{CDCl}_{3}\right) \delta 20.66(\mathrm{C}-4), 20.87\left(8-\mathrm{CH}_{3}\right)$, 31.53 (C-11), 45.79 (C-4a), 77.26 (C-10a), 116.81 (C-3a), 119.74 (C-5a), 120.04 (C-9), 126.87 (C-6), 127.44 (C-2",6"), 127.92 (C-3',5'), 128.07 (C-4"), 128.31 (C-7), 128.79 (C-3",5"), 129.03 (C-4"), 131.50 (C-1"), 131.70 (C-2',6'), 131.94 (C-1'), 132.93 (C-4"), 140.20 (C-11a), 145.41 (C8), 152.12 (C-3), 159.49 (C-9a), 167.80 (1-CO), 191.84 (C-5). EIMS m/z (\%) 464/466 (16, M+. $2 \mathrm{H}_{2}$ ), ${ }^{23} 359 / 361$ (2), 331/333 (4), 302/304 (2), 281 (4), 266 (2), 239 (5), 207 (6), 105 (100). Anal. calcd for $\mathrm{C}_{28} \mathrm{H}_{21} \mathrm{ClN}_{2} \mathrm{O}_{3}$ (468.93): C, 71.72; H, 4.51; N, 5.97. Found: C, 71.89; H, 4.60; N, $6.12 \%$.

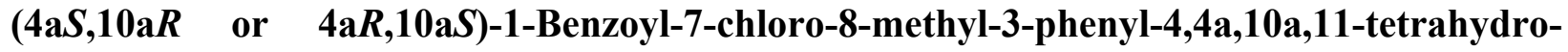
chromeno[3,2-f] indazol-5(1H)-one (12d). $0.141 \mathrm{~g}, 30 \%$ Yield. White solid $\left(\mathrm{CH}_{2} \mathrm{Cl}_{2}-\mathrm{Et}_{2} \mathrm{O}\right), \mathrm{mp}$ 217-219 ${ }^{\circ} \mathrm{C}$; IR (KBr) v $\max$ : 1690, 1647, 1629, 1604, 1451, $1360 \mathrm{~cm}^{-1} .{ }^{1} \mathrm{H}$ NMR $\delta 2.39$ (s, 3H, 8$\mathrm{CH}_{3}$ ), 2.95-3.05 (m, $\left.1 \mathrm{H}, 4 \mathrm{a}-\mathrm{H}\right), 2.90-3.10$ (m, 3H, 4,4a-H), 3.59 (dd, $J=19.2,4.4 \mathrm{~Hz}, 1 \mathrm{H}, 11-$ $\left.\mathrm{H}_{\mathrm{ax}}\right), 3.825\left(\mathrm{dd}, J=19.2,2.5 \mathrm{~Hz}, 1 \mathrm{H}, 11-\mathrm{H}_{\mathrm{eq}}\right), 5.02-5.10(\mathrm{~m}, 1 \mathrm{H}, 10 \mathrm{a}-\mathrm{H}), 6.919$ (s, 1H, 9-H), 7.34-7.46 (m, 3H, 3",4',5"-H), 7.46-7.53 (m, 2H, 3',5'-H), 7.58-7.63 (m, 1H, 4"-H), 7.67-7.71 (m, 2H, 2",6"-H), 7.897 (s, 1H, 6-H), 8.13-8.17 (m, 2H, 2',6'-H). ${ }^{13} \mathrm{C} \mathrm{NMR}\left(75 \mathrm{MHz}, \mathrm{CDCl}_{3}\right) \delta$ 20.31 (C-4), $20.88\left(8-\mathrm{CH}_{3}\right), 30.06$ (C-11), 44.64 (C-5a), 75.01 (C-10a), 116.71 (C-3a), 118.37 
(C-5a), 120.15 (C-9), 127.32 (C-6), 127.50 (C-2",6"), 127.96 (C-3',5'), 128.27 (C-7), 128.73 (C3",5"), 129.01 (C-4"), 131.74 (C-2',6'), 132.02 (C-1"), 132.60 (C-1'), 132.77 (C-4'), 140.08 (C11a), 145.53 (C-8), 152.19 (C-3), 159.01 (C-9a), 168.06 (1-CO), 192.99 (C-5). EIMS m/z (\%) 464/466 (12, M ${ }^{+}$), 331 (4), 281 (6), 239 (10), 207 (8), 105 (100). Anal. calcd for $\mathrm{C}_{28} \mathrm{H}_{21} \mathrm{ClN}_{2} \mathrm{O}_{3}$ (468.93): C, 71.72; H, 4.51; N, 5.97. Found: C, 71.59; H, 4.67; N, 6.13\%.

\section{From compound $3 \mathrm{e}$}

(4aR,10aR or 4aS,10aS)-1-Benzoyl-7-nitro-3-phenyl-4,4a,10a,11-tetrahydrochromeno[3,2$f$ lindazol-5(1H)-one (11e). $10 \%$ Yield. ${ }^{24}{ }^{1} \mathrm{H}$ NMR $\delta 2.85-3.01\left(\mathrm{~m}, 1 \mathrm{H}, 4-\mathrm{H}_{\mathrm{ax}}\right), 3.10-3.20(\mathrm{~m}$, $\left.1 \mathrm{H}, 4 \mathrm{a}-\mathrm{H}_{\mathrm{ax}}\right), 3.75-3.85\left(\mathrm{~m}, 1 \mathrm{H}, 11-\mathrm{H}_{\mathrm{eq}}\right), 3.77$ (dd, $\left.J=19.1,4.8 \mathrm{~Hz}, 1 \mathrm{H}, 4-\mathrm{H}\right), 4.176$ (dd, $J=17.5$, $\left.6.3 \mathrm{~Hz}, 1 \mathrm{H}, 11-\mathrm{H}_{\mathrm{eq}}\right), 4.859$ (ddd, $\left.J=13.1,9.6,6.6 \mathrm{~Hz}, 1 \mathrm{H}, 10 \mathrm{a}-\mathrm{H}\right), 7.224(\mathrm{~d}, J=9.1 \mathrm{~Hz}, 1 \mathrm{H}, 9-$ H), 7.40-7.65 (m, 6H, 3', 4',5',3",4",5"-H), 7.75-7.82 (m, 2H, 2",6"-H), 8.16-8.18 (m, 2H, 2',6'H), 8.408 (dd, $J=9.1,2.6 \mathrm{~Hz}, 1 \mathrm{H}, 6-\mathrm{H}), 8.85(\mathrm{~d}, J=2.6 \mathrm{~Hz}, 1 \mathrm{H}, 6-\mathrm{H})$. No other experimental data are available due to transformation to $\mathbf{1 5}$ upon purification on prep. TLC.

1-Benzoyl-5-(2-hydroxy-5-nitrobenzoyl)-3-phenyl-1H-indazole (15). White solid $\left(\mathrm{CH}_{2} \mathrm{Cl}_{2}-\right.$ $\left.\mathrm{Et}_{2} \mathrm{O}\right), \mathrm{mp} 232-235{ }^{\circ} \mathrm{C} ;{ }^{1} \mathrm{H}$ NMR $\delta 7.24(\mathrm{~d}, J=9.2 \mathrm{~Hz}, 1 \mathrm{H}, 11-\mathrm{H}), 7.52-7.61(\mathrm{~m}, 5 \mathrm{H}$, 3',5',3",4",5"-H), 7.662 (tt, $\left.J=7.6,1.6 \mathrm{~Hz}, 1 \mathrm{H}, 4^{\prime}-\mathrm{H}\right), 7.95-7.99$ (m, 2H, 2",6"-H), 8.032 (dd, $J=$ $8.8,1.85 \mathrm{~Hz}, 1 \mathrm{H}, 6-\mathrm{H}), 8.21-8.26\left(\mathrm{~m}, 2 \mathrm{H}, 2^{\prime}, 6^{\prime}-\mathrm{H}\right), 8.436$ (dd, $\left.J=9.2,2.8 \mathrm{~Hz}, 1 \mathrm{H}, 12-\mathrm{H}\right), 8.450$ (dd, $J=1.85,0.7 \mathrm{~Hz}, 1 \mathrm{H}, 4-\mathrm{H}), 8.706(\mathrm{~d}, J=2.8 \mathrm{~Hz}, 1 \mathrm{H}, 14-\mathrm{H}), 8.846(\mathrm{dd}, J=8.8,0.7 \mathrm{~Hz}, 1 \mathrm{H}$, 7-H), 12.6 (br s, $1 \mathrm{H}, \mathrm{OH}) .{ }^{13} \mathrm{C}$ NMR $\left(75 \mathrm{MHz}, \mathrm{CDCl}_{3}\right) \delta 116.89$ (C-7), 118.10 (C-9), 119.83 (CH), 123.33, 123.95, 124.62, $129.52(\mathrm{CH}), 128.15$ (C-3',5'), 128.32 (C-3",5"), 129.28 (C-2",6"), 130.05 (C-4"), $130.11(\mathrm{CH}), 130.90$ (C-1"), 131.08 (C-12), 131.57 (C-2',6'), 132.84 (C-4'), 133.15 (C-1'), 136.05 (C-5), 139.63 (C-13), 143.70 (C-7a), 151.92 (C-3), 163.20 (C-10), 168.03 (1-CO), 199.43 (C-8). Anal. calcd for $\mathrm{C}_{27} \mathrm{H}_{17} \mathrm{~N}_{3} \mathrm{O}_{5}$ (463.441): C, 69.97; H, 3.70; N, 9.07. Found: $\mathrm{C}, 70.31 ; \mathrm{H}, 3.82 ; \mathrm{N}, 8.92 \%$.

(4aS,10aR or 4aR,10aS)-1-Benzoyl-7-nitro-3-phenyl-4,4a,10a,11-tetrahydrochromeno[3,2flindazol-5(1H)-one (12e). $0.098 \mathrm{~g}, 21 \%$ Yield. White solid $\left(\mathrm{CH}_{2} \mathrm{Cl}_{2}-\mathrm{Et}_{2} \mathrm{O}\right), \mathrm{mp} 228-230{ }^{\circ} \mathrm{C}$; IR (KBr) $v_{\max }: 1695,1616,1585,1526,1350,1279 \mathrm{~cm}^{-1} .{ }^{1} \mathrm{H}$ NMR $\delta 2.99-3.05\left(\mathrm{~m}, 1 \mathrm{H}, 4-\mathrm{H}_{\mathrm{ax}}\right)$, 3.05-3.11 (m, 1H, 4- $\left.\mathrm{H}_{\mathrm{eq}}\right), 3.125$ (td, $\left.J=5.8,2.5 \mathrm{~Hz}, 1 \mathrm{H}, 4 \mathrm{a}-\mathrm{H}\right), 3.663$ (dd, $J=19.3,4.8 \mathrm{~Hz}, 1 \mathrm{H}$, $11-\mathrm{H}_{\mathrm{ax}}$ ), 3.87 (dd, $\left.J=19.3,2.8 \mathrm{~Hz}, 1 \mathrm{H}, 11-\mathrm{H}_{\mathrm{eq}}\right), 5.20$ (ddd, $\left.J=4.8,2.8,2.5 \mathrm{~Hz}, 1 \mathrm{H}, 10 \mathrm{a}-\mathrm{H}\right)$, 7.168 (d, $J=9.15 \mathrm{~Hz}, 1 \mathrm{H}, 9-\mathrm{H}), 7.37-7.45$ (m, 3H, 3",4",5"-H), 7.47-7.55 (m, 2H, 3',5'-H), 7.620 (tt, $\left.J=7.4,1.3 \mathrm{~Hz}, 1 \mathrm{H}, 4^{\prime}-\mathrm{H}\right), 7.67-7.71$ (m, 2H, 2",6"-H), 8.13-8.18 (m, 2H, 2',6'-H), 8.375 (dd, $J=9.15,2.85 \mathrm{~Hz}, 1 \mathrm{H}, 8-\mathrm{H}), 8.846(\mathrm{~d}, J=2.85 \mathrm{~Hz}, 1 \mathrm{H}, 6-\mathrm{H}) .{ }^{13} \mathrm{C}$ NMR $(75 \mathrm{MHz}$, $\left.\mathrm{CDCl}_{3}\right) \delta 19.99(\mathrm{C}-4), 29.74(\mathrm{C}-11), 44.45$ (C-4a), 75.84 (C-10a), 116.15 (C-3a), $119.48(\mathrm{C}-9)$, 124.21 (C-6), 127.45 (C-2",6"), 127.99 (C-3',5'), 128.48 (C-5a), 128.78 (C-3",5"), 129.12 (C-4"), 130.62 (C-8), 131.55 (C-1"), 131.73 (C-2',6'), 132.36 (C-1'), 132.90 (C-4'), 139.52 (C-11a), 142.62 (C-7), 152.16 (C-3), 164.56 (C-9a), 168.00 (1-CO), 191.92 (C-5). EIMS m/z (\%) 461 (9, $\mathrm{M}^{+\cdot}-2 \mathrm{H}_{2}$ ), ${ }^{23} 431$ (27), 355 (5), 327 (6), 298 (7), 281 (25), 224 (5), 207 (55), 191 (7), 133 (5), 105 (100). Anal. calcd for $\mathrm{C}_{27} \mathrm{H}_{19} \mathrm{~N}_{3} \mathrm{O}_{5}$ (465.46): C, 69.67; H, 4.11; N, 9.03. Found: C, 69.54; $\mathrm{H}$, $4.23 ; \mathrm{N}, 9.20 \%$. 


\section{References and Notes}

1. (a) Dewick, P. M. In The Flavonoids: Advances in Research Since 1986; Harborne, J. B., Ed.; Chapmann \& Hall: New York, 1994; p 23. (b) Gill, M. In The Chemistry of Natural Products; Thomson, R. H. Ed.; $2^{\text {nd }}$ Ed., Blackie: Surrey, 1993; p 60. (c) Manthy, J. A.; Buslig, B. S.; Eds.; In Flavonoids in the Living Systems: Advances in Experimental Medicine and Biology; Plenum: New York, 1998; Vol. 439. (c) Levai A. Arkivoc 2004, 15. (d) Silva, A. M. S.; Pinto, D. C. G. A.; Cavaleiro, J. A. S.; Levai, A.; Patonay, T. Arkivoc 2004, 106.

2. (a) Korkina, G. L.; Alafan'ev, I. B. Advances in Pharmacology; Sies, H., Ed.; Academic: San Diego, 1997; Vol. 38, p.151. (b) Hansch, C.; Sammes, P. G.; Taylor, J. B., Edt.; Comprehensive Medicinal Chemistry; Pergamon: London 1990; Vol. 6.

3. (a) Ghosh, C. K.; Ghosh, C. Indian J. Chem. 1997, 36B, 968. (b) Hsung, R. P. J. Org. Chem. 1997, 62, 7904. (c) Valenti, P.; Bisi, A.; Rampa, A.; Belluti, F.; Gobbi, S.; Zampiron, A.; Carrara, M. Bioorg. Med. Chem. 2000, 8, 239. (d) Malhotra, S.; Shakya, G.; Kumar, A.; Vanhoecke, B. W.; Cholli, A. L.; Raj, H.G.; Saso, L.; Ghosh, B.; Bracke, M. E.; Prasad, A. K.; Biswal, S.; Parmar, V. S. ARKIVOC 2008, (vi), 119. (e) Singh, G.; Singh, R.; Girdhar, N. K.; Ishar, M. P. S. Tetrahedron 2002, 58, 2471.

4. (a) Kumar, S. K. J. Med. Chem. 2003, 46, 2813; (b) Wang, Y. Q.; Bioorg. Med. Chem. 2003, 11, 1569; (c) Gao, Y.; Li, D. J.; Keung, W. M. Bioorg. Med. Chem. 2003, 11, 4069; (d) Ishar, M. P. S.; Singh, G.; Singh, S.; Sreenivasan K. K.; Singh G. Bioorg. Med. Chem. Lett. 2006, 16, 1366.

5. For a review on the biological activities and synthesis of chromone derivatives see: Horton, D. A.; Bourne, G. T.; Smythe, M. L. Chem. Rev. 2003, 103, 893.

6. (a) Martínez-Grau, A.; Marco, J. L. Bioorg. Med. Chem.Lett. 1997, 24, 3165. (b) Mohr, S. J.; Chirigos, M. A.; Fuhrman, F. S.; Pryor, J. W. Cancer Res. 1975, 35, 3750. (c) El-Agrody, A. M.; El-Hakim, M. H.; Abd El-Latif, M. S.; Fakery, A. H.; El-Sayed E. S. M.; El-Ghareab, K. A. Acta Pharm. 2000, 50, 111.

7. (a) Ghosh, C. K. J. Heterocycl. Chem. 1983, 20, 1437; (b) Ghosh, C. K. Indian J. Chem. 1997, 36B, 968; (c) Ghosh, C. K. Heterocycles 2004, 63, 2875.

8. (a) Sabitha, G. Aldrichim. Acta 1996, 29, p 5 and references cited therein. (b) Ghosh, C.; Tewari, N. J. Org. Chem. 1980, 45, 1964.

9. (a) Kona, J.; Fabian, W. M. F.; Zahradnik, P. J. Chem. Soc., Perkin Trans. 2 2001, 422. (b) Kona, J.; Zahradnik, P.; Fabian, W. M. F. J. Org. Chem. 2001, 66, 4998.

10. Borrell, J. I.; Teixido, J.; Schuler, E.; Michelotti, E. Tetrahedron Lett. 2001, 42, 5331.

11. (a) Sandulache, A.; Silva, A. M. S.; Cavaleiro, J. A. S. Tetrahedron 2002, 56, 105. (b) Sandulache, A.; Silva, A. M. S.; Cavaleiro, J. A. S. Monatsch. Chem. 2003, 134, 551. (c) Cremins, P. J.; Saengchantara, S. T.; Wallace, T. W. Tetrahedron 1987, 43, 3075.

12. (a) Pozarentzi, M.; Stephanidou-Stephanatou, J.; Tsoleridis, C. A. Tetrahedron Lett. 2003, 44, 2007. (b) Neochoritis, C.; Livadiotou, D.; Stephanidou-Stephanatou, J.; Tsoleridis C. A. 
Tetrahedron Lett. 2007, 48, 2275. (c) Neochoritis, C.; Stephanidou-Stephanatou, J.; Tsoleridis C. A. Synlett. 2007, 16, 2596.

13. Terzidis, M.; Tsoleridis, C. A.; Stephanidou-Stephanatou J. Tetrahedron Lett. 2005, 46, 7239.

14. (a) Saroya, B.; Srinivasan, P.C. Tetrahedron Lett. 1984, 25, 5429. (b) Pindur, U.; Gonzalez, E.; Mehrabani, F. J. Chem. Soc., Perkin Trans. I 1997, 1861.

15. Mitkidou, S.; Stephanidou-Stephanatou, J. Tetrahedron Lett. 1990, 31, 5197.

16. Terzidis, M.; Tsoleridis, C. A.; Stephanidou-Stephanatou J. Tetrahedron 2007, 63, 7828.

17. For most compounds the spin system of the saturated protons as well as of the aromatic protons has also been studied by simulation (SpinWorks ver. 2.5).

18. McIver Jr., J. W.; Komornicki, A. J. Am. Chem. Soc. 1972, 94, 2625.

19. Di Valentin, C.; Freccero, M.; Sarzi-Amadè, Zanalettti, R. Tetrahedron 2000, 56, 2547.

20. (a) Nohara, A.; Sugihara, H.; Ukawa, K. Jpn Patent; Chem. Abstr. 1986, 104, 186390. (b) Nohara, A.; Sugihara, H.; Ukawa, K. Jpn Patent; Chem. Abstr. 1986, 104, 207250.

21. MOPAC 2000 ver. 1.11, Fujitsu.

22. Only the distinct peaks of ${ }^{1} \mathrm{H} \mathrm{nmr}$ are presented, due to the overlapping. Carbon chemial shifts of the minor isomers were assigned by estimation acccordingly to the major isomers.

23. The compound was aromatized during the separation process in the column loosing $2 \mathrm{H}_{2}$.

24. The composition was computed from the ${ }^{1} \mathrm{H} \mathrm{nmr}$. 